\title{
Clay combustion structures in early Mesolithic at Cova da Baleia (Mafra, Portugal): Approaches to their functionality
}

\author{
Ana Catarina Sousa ${ }^{\mathrm{a}, *}$, Juan Gibaja Bao ${ }^{\mathrm{b}}$, Niccolo Mazzuco ${ }^{\mathrm{d}}$, Marta Miranda ${ }^{\mathrm{c}}$, \\ João Pedro Vicente Tereso ${ }^{\mathrm{a}, \mathrm{e}}$, Cláudia Oliveira ${ }^{\mathrm{e}}$, Victor S. Gonçalves ${ }^{\mathrm{a}}$ \\ ${ }^{\text {a } U N I A R Q, ~ C e n t e r ~ f o r ~ A r c h a e o l o g y ~ o f ~ t h e ~ L i s b o n ~ U n i v e r s i t y, ~ F a c u l t y ~ o f ~ L e t t e r s, ~ U n i v e r s i t y ~ o f ~ L i s b o n, ~ A l a m e d a ~ d a ~ U n i v e r s i d a d e, ~ 1600-214 ~ L i s b o a, ~ P o r t u g a l ~}$ \\ ${ }^{\mathrm{b}}$ Institución Milà i Fontanals (MF-CSIC), C/Egipcíaques 15, Barcelona, 08001, Spain \\ ' Câmara Municipal de Mafra, Praça do Municipio, 2640 Mafra, Portugal \\ ' UMR 7055 'Préhistoire et Technologie', CNRS-Université Paris Ouest Nanterre la Défense, 21 Allée de l'Université, F-92023 Nanterre Cedex, France \\ e InBIO - Rede de Investigação em Biodiversidade e Biologia Evolutiva, Lab. Associado/CIBIO - Centro de Investigação em Biodiversidade e Recursos Genéticos, Univ. Porto. \\ Uniarq - Centro de Arqueologia da Universidade de Lisboa, Portugal
}

\section{A R T I C L E I N F O}

\section{Keywords:}

Mesolithic

clay structures

fire

Portugal

\begin{abstract}
A B S T R A C T
The functionality of Cova da Baleia (Mafra, Portugal) is hereby presented and discussed in this paper. In an excavated area of $500 \mathrm{~m}^{2}$ was identified a large concentration of structures (128), of which 104 were in clay, with two phases of occupation. The absolute chronology indicates a majority occupation of the second half of the 8th millennium cal BCE (Early Mesolithic) and a second phase towards the end of the 7th millennium (Late Mesolithic). Despite the excellent state of conservation of the site, the osteological remains are practically absent, possibly due to taphonomic factors.

Cova da Baleia is clearly a distinctive site of the reference framework known of the Early Mesolithic times in Portugal, given the large size of the site (about $1 \mathrm{ha}$ ) and its structural complexity.

It was clear that an interdisciplinary approach was mandatory in order to fully guarantee the site interpretation, namely regarding its functionality. The results of the use-wear and archaeobotanical studies show the relevance of wood and other hard materials, whereas the need for fire for these activities remains to be understood.
\end{abstract}

\section{Introduction}

Today there are still only a few archaeological sites from the Early Mesolithic (Pre-Boreal and Boreal - 8200-6200 cal BCE) in Portugal (Fig. 1). They're mostly concentrated in Estremadura, integrating three functional categories: 1 . shell middens; 2 . terrestrial open-air sites; 3 . shelters and caves (Araújo, 2011). These three types occur in distinct geographic areas: the shell middens, on the Atlantic coast; the open-air sites and caves in the Estremadura Limestone Massif. The available information is fragmented, with excavations of reduced and unequal context preservation. The shell middens constitute the more frequent and most intensely researched sites. The terrestrial open-air sites are very scarce, which can be explained by their difficult detection.

Given this scenario, was proposed a model that advocates high levels of mobility in Estremadura (Araújo et al., 2014, p. 32), with logistic sites (shell middens and shelters) and residential sites, in lower areas. Until now, the only identified sites that might be residential have been found in the region of Rio Maior: Cabeço de Porto Marinho 5 (Zilhão,
1997), Areeiro 3 (Bicho, 2000) and Fonte Pinheiro (Bicho, 1994).

Therefore, the site at Cova da Baleia assumes great importance. Within the framework of preventive archaeology, the 2007 excavation allowed the identification of a new site typology with a high number of clay structures, completely different from those known until then for the Early Mesolithic in Estremadura (Sousa and Gonçalves, 2015).

Sites with numerous clay structures, concentrated in nuclei, were identified in the South of Portugal, namely in the area of Baixa do Xarez, where the interventions in Xarez 12 and Carraça 1 (Gonçalves, 2003; Gonçalves et al., 2008; Gonçalves et al., 2013) took place. Subsequent interventions were later carried out in other contexts in the area of Évora (Gaspar et al., 2009; Santos and Carvalho, 2008). Radiocarbon dating was not possible in any of these sites, but the material culture seems to indicate a chronology of the Late Mesolithic and Early Neolithic.

The present paper seeks to distinguish the functionality of Cova da Baleia based on structures, materials and absolute chronologies, using use-wear analysis and anthracology as supplementary tools.

\footnotetext{
* Corresponding author.

E-mail address: sousa@campus.ul.pt (A.C. Sousa).
} 


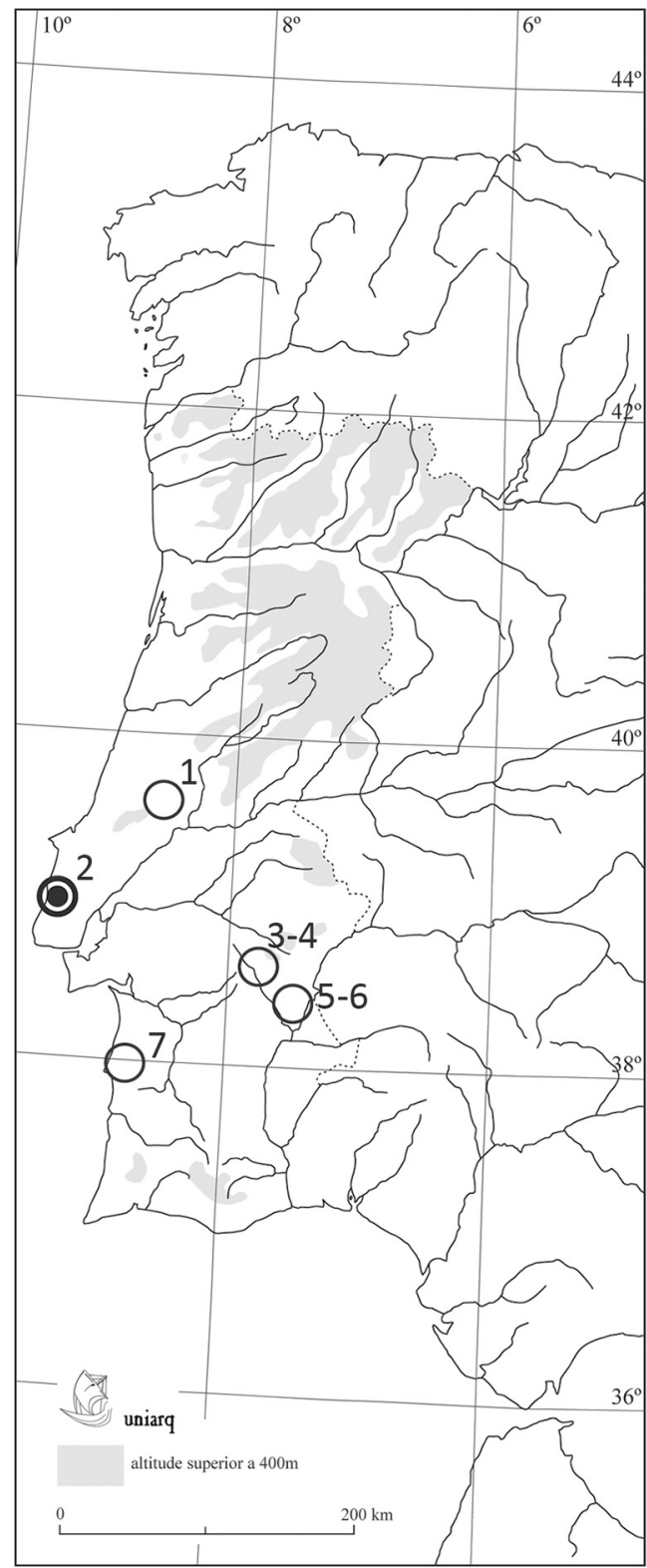

Fig. 1. Location of Cova da Baleia and other contexts with clay combustion structures in central and southern Portugal: 1-Fonte; 2-Cova da Baleia; 3-Defesa de Cima; 4-Lajinha 8; 5-Carraça 1; 6-Xarez 12; 7 - Salema.

\section{Cova da Baleia: the data}

The archaeological work in Cova da Baleia was part of a preventive archaeological intervention performed in 2007, with a total excavated area of $500 \mathrm{~m}^{2}$. The prehistoric occupation is located on a soft slope (170-150 m), covering an area of about 1 ha in two contiguous valleys (Figs. 2, 3).

Cova da Baleia is located in the Lisbon Peninsula, in the county of Mafra, at $9^{\circ} 20^{\prime} 311^{\prime \prime}$ latitude; $38^{\circ} 58^{\prime} 434^{\prime \prime}$ longitude (geographic coordinates) and - 104,271,666 (X), - 76,275,678 (Y), $170 \mathrm{~m}(\mathrm{Z})$ (Gauss coordinates; Datum Lisboa).

The site is on the left bank of the Ribeira do Cuco tributary, a stream that drains into the Atlantic Ocean. Presently, Cova da Baleia is located about $9 \mathrm{~km}$ from the ocean, but the coastline may have been further inland during the prehistoric occupation of the location (Dias, 2004).

\subsection{Stratigraphy}

The occupation of Cova da Baleia is situated on a gentle slope (ranging from 170 to $150 \mathrm{~m}$ ), with an occupied area of about 1 ha. Its implantation in a slope would have potentiated the deposition of colluvium, with a thick stratigraphic deposition, following the slope.

In an area of intense agricultural work, the conservation of the Cova da Baleia contexts was only possible due to the existence of very specific depositional circumstances: a recent water line that possibly prevented the use of agricultural machinery in the adjacent area.

The water line (S.U. 3) created a deep trench, which cut many archaeological contexts (clay combustion structures and other structures (see Fig. 4). The orientation of this trench follows the North-South direction, positioned at the juncture of coordinates 8 and 9 . The width of this trench is variable, on average it registers $0.3 \mathrm{~m}$ wide, although in some sections it can reach $1 \mathrm{~m}$. The depth of this trench is also variable, accompanying the slope, which affects more deeply the structures were preserved in lower slope (see Fig. 5).

The excavation uncovered a number of archaeological vestiges including 128 structures, of which 104 correspond to burnt clay structures, with distinct typologies (Fig. 4).

Three large sedimentary horizons were identified (Figs. 6, 7):

1. Superficial humus layer, mechanically excavated during land clearance (U.E. 0).

2. Very compact deposit (U.E. 1), with a thickness varying between $2 \mathrm{~m}$ and $0.5 \mathrm{~m}$, along the slope. The sediment presents scarce archaeological materials and reduced stone blocks, as well as some mid-level structures. This extremely homogeneous deposit resulting from a process of pedogenesis may include several phases of the occupation.

3. Palaeosol (U.E. 7), from which a very high number of clay structures (73) and pits (Bicho, 1994) were excavated, corresponding to $80 \%$ of the identified structures. The structures were organized in nuclei, possibly corresponding to a horizontal stratigraphy.

The conjugation of stratigraphic data, positioning of structures and dating materials seems to indicate the existence of the following stages of occupation, from the oldest to the most recent (Fig. 8):

Phase 1: occupation of the slope and successive construction of structures upon the palaeosol. Integrates all the clay oven-type structures, pits and stone pavements, associated with an occupation layer containing a considerable number of archaeological materials;

Phase 2: occupation of the slope, with the presence of clay structures (thermal slabs), stone pavements and postholes;

Phase 3: A burial deposit (NMI 2 and 52 theet);

Phase 4: Recent rural use of the soil.

\subsection{Features}

Generically, three main types of structures can be identified: 1) clay structures; 2) stone structures; 3) pits (Table 1).

\subsubsection{Clay structures (1)}

The structures that integrate burnt clay correspond to the most numerous group (total of 104), highlighting the importance of this resource for the construction of structures during the full diachrony of occupation. Two different types of structure were identified.

- Clay pits or kilns (1.1.), excavated in the palaeosol and with signs of combustion (abundant charcoal, stone thermal slabs or thermally altered stones). Most of the structures (58\%) were excavated, while the remaining structures were only defined at the surface. They present subcircular or oval shapes, with different typologies: domed (1.1.1), tronco-conical (1.1.2), and structures that integrate a claystone mixture (1.13). Their state of conservation was excellent, 


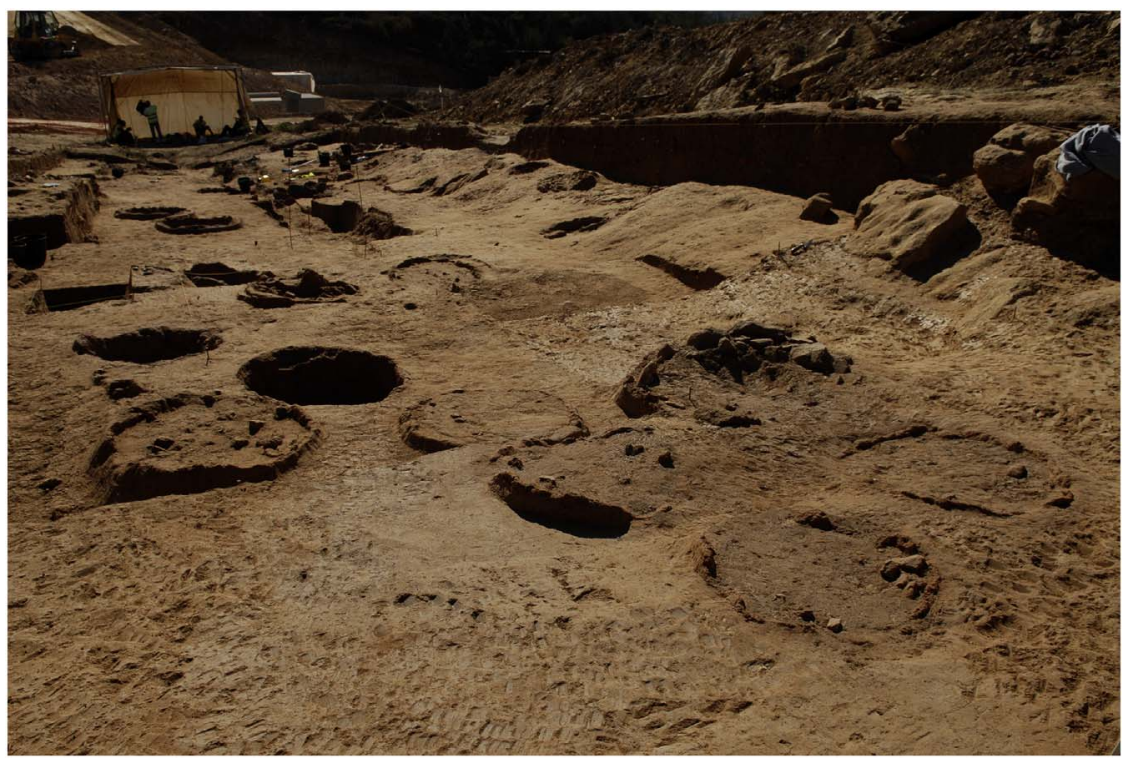

Fig. 2. General view of Cova da Baleia with clay pits/kilns (phase $1)$.

corresponding to $88 \%$ of the clay structures in Cova da Baleia.

- Clay slabs (1.2), at an intermediate stratigraphic level, presenting low level of aggregation, very irregular forms and including some blocks of stone. May be related with combustion, as there are some thermally altered stones and charcoal associated to them.

\subsubsection{Stone structures (2)}

In the large part of the stone clusters (10 in 19), no concrete functionality was identified, possibly corresponding to dismantled structures. The stone structures integrate blocks of local raw material (limestone) of different dimensions. The following types were registered:

- Structured post holes (2.1), concentrated in a restricted area, in the second phase of occupation.

- Stone pavements (2.2), probably also associated with combustion, with thermally altered stones.

\subsubsection{Pits (3)}

Negative structures filled with anthropogenic sediment, ovalshaped, cutting directly into the palaeosol. Also register some signs of combustion.

\subsection{Radiocarbon dates}

Until now, six radiocarbons dates have been obtained, with samples selected among different types of structures in differentiated areas. All dates were obtained from charcoal (Fig. 9, Table 2).

Dating was attempted from the human burial (U.E.6), but the sample did not contain collagen. A sample from a Cerastoderma edule shell also presented problems, as the delta $13 \mathrm{C}$ value was anomalous, preventimg calibration and calculation of the reservoir effect. Two hypotheses can be considered: post-depositional contamination or freshwater environment, preventing calibration.

Samples Beta-294,170, Beta-295,903, Beta-295,904, and Beta295,905 were collected inside the ovens in well preserved and closed contexts. We opted to date different types of clay structures, from different locations. Dating short-lived plant species was not possible as these are inexistent in the charcoal assemblages (vide infra). However, we highlight the coherence of the dates obtained, indicating a chronology of the second half of the 8th millennium, in the first phase of occupation.

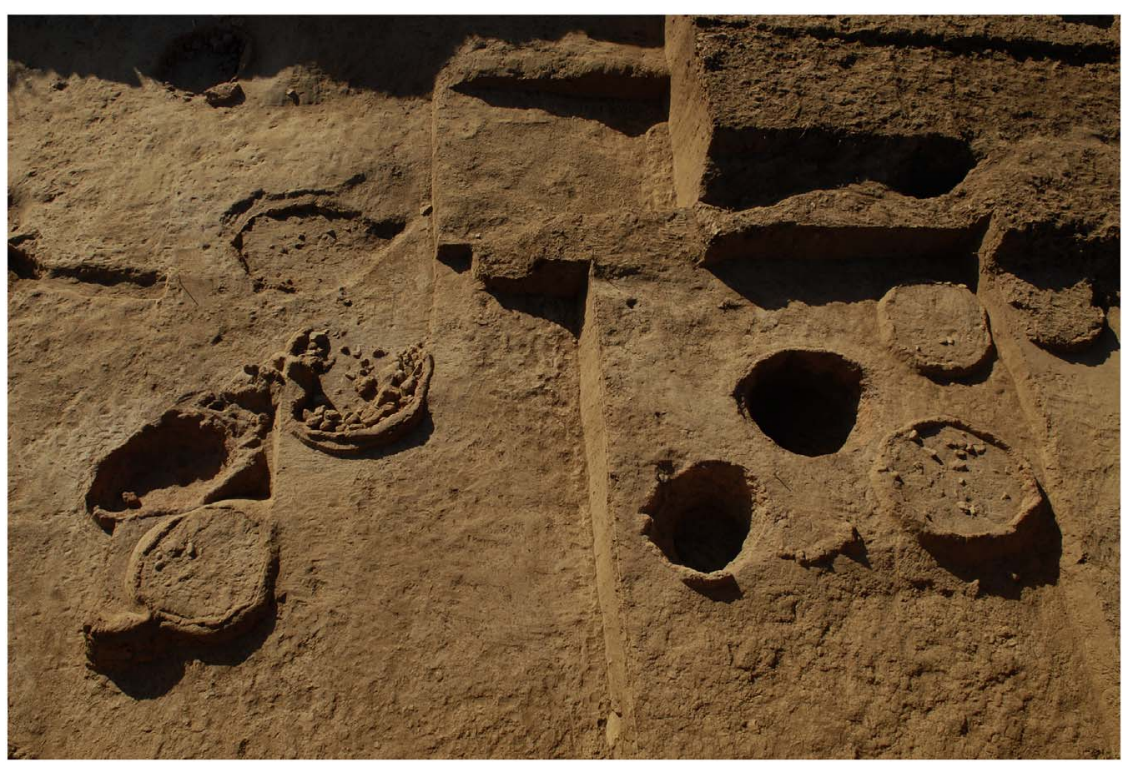

Fig. 3. Clusters of clay combustion structures (phase 1). 

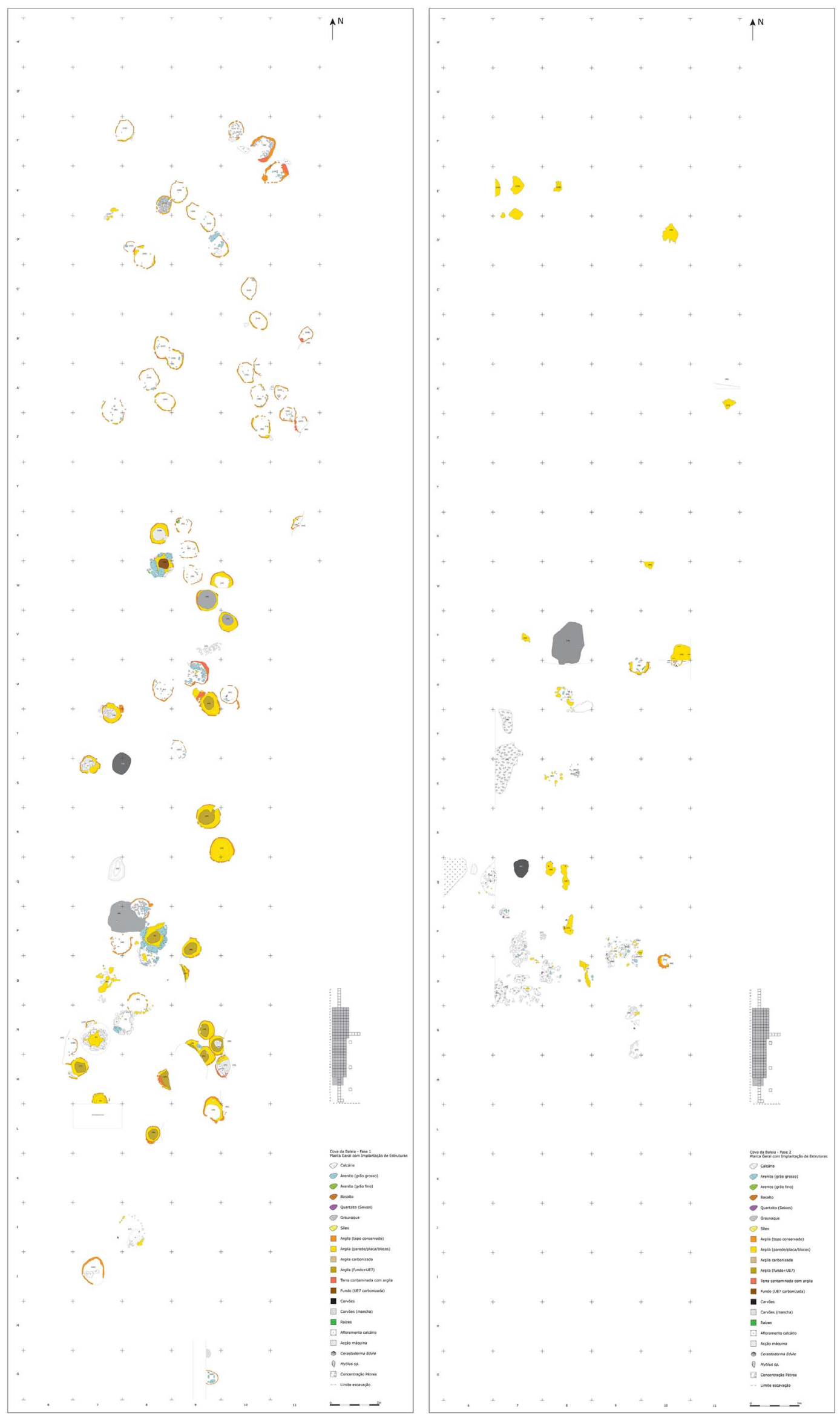

Phase 1

Phase 2

Fig. 4. Composed plans of Cova da Baleia - phase 1 and 2. 


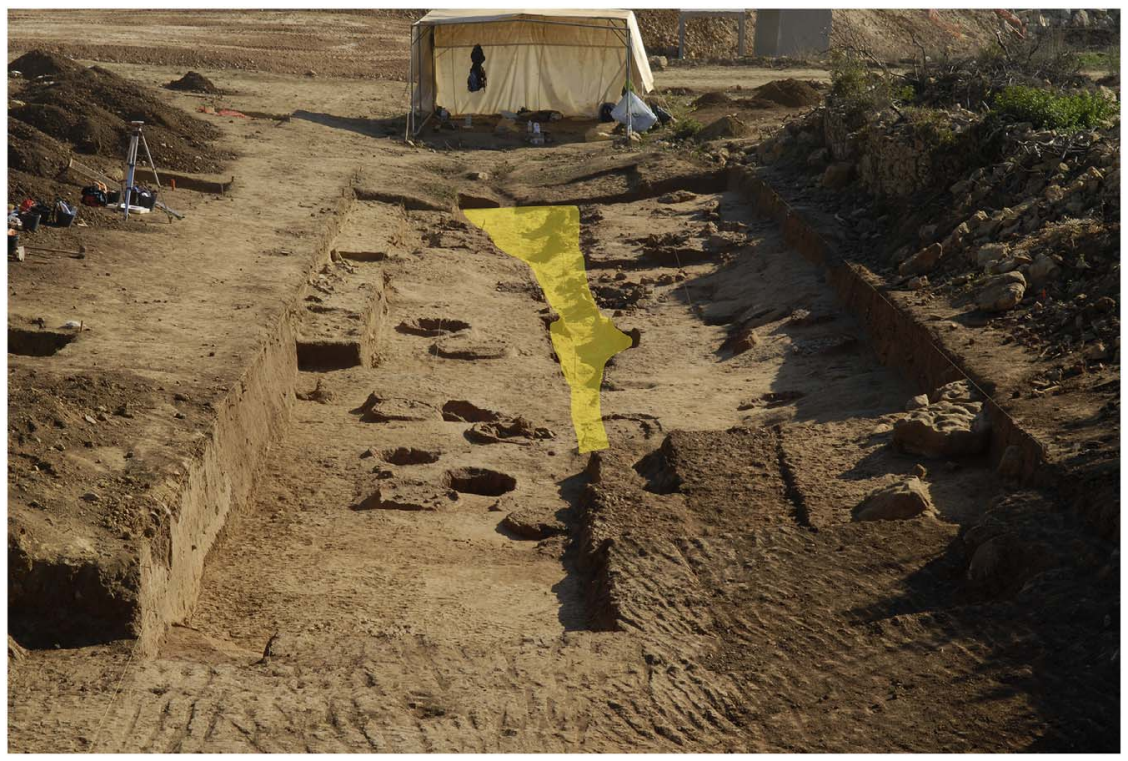

Fig. 5. General view of Cova da Baleia with indication of water drainage ditch.

Dating of the second phase was more complex, given the «open» typology of the structures and the scarce amount of charcoal. We selected two samples of charcoal collected near clay slabs. One of the dated samples, Beta-464,381, was included in a chronologic tier from the Middle and Late Mesolithic, in the final quartile of the 7th millennium cal BCE. The other sample, Beta-464,382, is older than expected and can be included in the first phase. It is plausible there was a stratigraphic disturbance, given that this structure is located near a water runoff ditch that cuts through the location longitudinally (S.U. 3).

Despite the need for more dates, those already obtained allow a number of observations:

1. The first phase of occupation of Cova da Baleia dates back to the middle of the 8th millennium (Boreal, early Mesolithic). It is the main phase of occupation, with 73 fire structures.

2. No chronological gradients were detected in the different types of structures dated from the first phase of occupation.

3. For now, a second phase of occupation is documented and dated to the 7th millennium, corresponding to the Atlantic chronozone, in the Mid-Mesolithic.

4. The analysis of the material culture seems to indicate the presence of an Early Neolithic phase, denounced by the presence of some ceramic fragments, namely with cardial decoration, and some lithic materials (geometric). The burials may be associated with this phase.

\subsection{Material culture}

In general, archaeological materials are not well preserved. The lithic materials present poor surface conservation. The ceramics are very fragmented and with eroded surfaces. Given the geologic substrate of the site (limestone), the preservation of organic material (bone and shells) would be expected. However, bone fragments are absent. Although the reason is not clear, it is possible there were differences in preservation.

The archaeological density of Cova da Baleia is low, corresponding to only 13 pieces per $\mathrm{m}^{2}$, although the spatial distribution is not uniform.

Globally, we can consider that all phases of the chaine operatoire are represented (Table 3), with clear evidence of debitage at the site in both phases. Lithic reduction was oriented towards obtaining flakes, with bladelets and, residually, blades also represented (Table 2).

The separation of the material by phases was somewhat difficult, in particular the groups not directly associated with structures from phases 1 and 2 (Figs. 4, 6). The values are relatively equivalent, with small differences.

Within the tools, there are a large number of notches (31\% of tools), produced mostly over flakes and also over blade, bladelet, nucleus, lithic waste. The remaining tools are dominated by retouched flakes and non-standard supports.

The geometric armatures, produced over blades and bladelets, are absent from phase 1 , as in other contemporary assemblages, namely in Toledo and Vale Frade (Araújo, 2011). Among the small number of
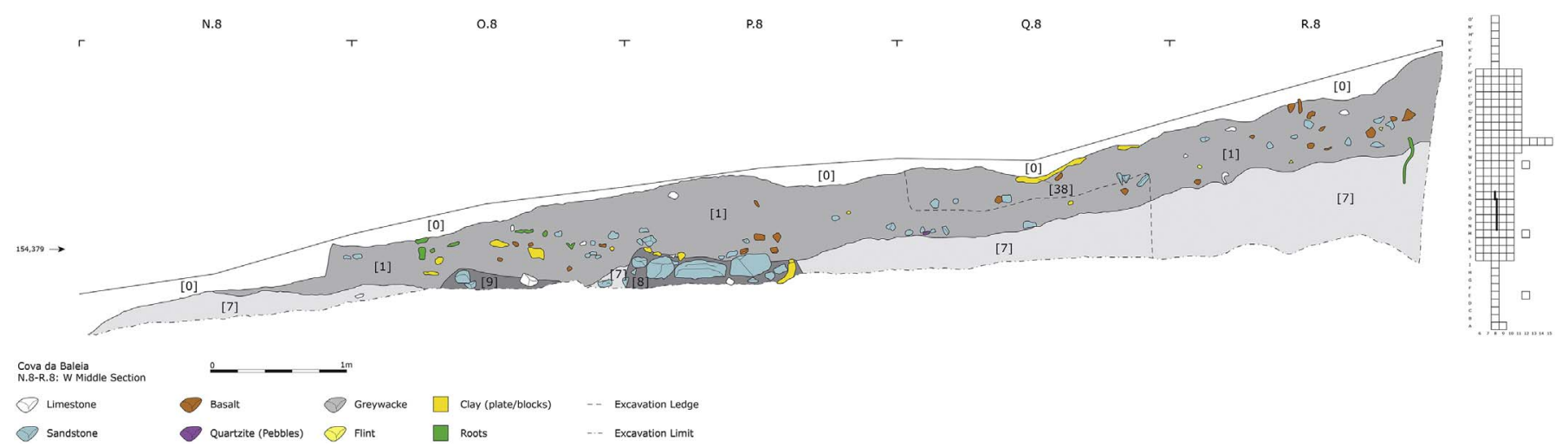

Fig. 6. Stratigraphic section of Cova da Baleia (West) with remains of phase 2 (S.U. 38) and phase 1 (S.U. 8, 9 and layer 7). 

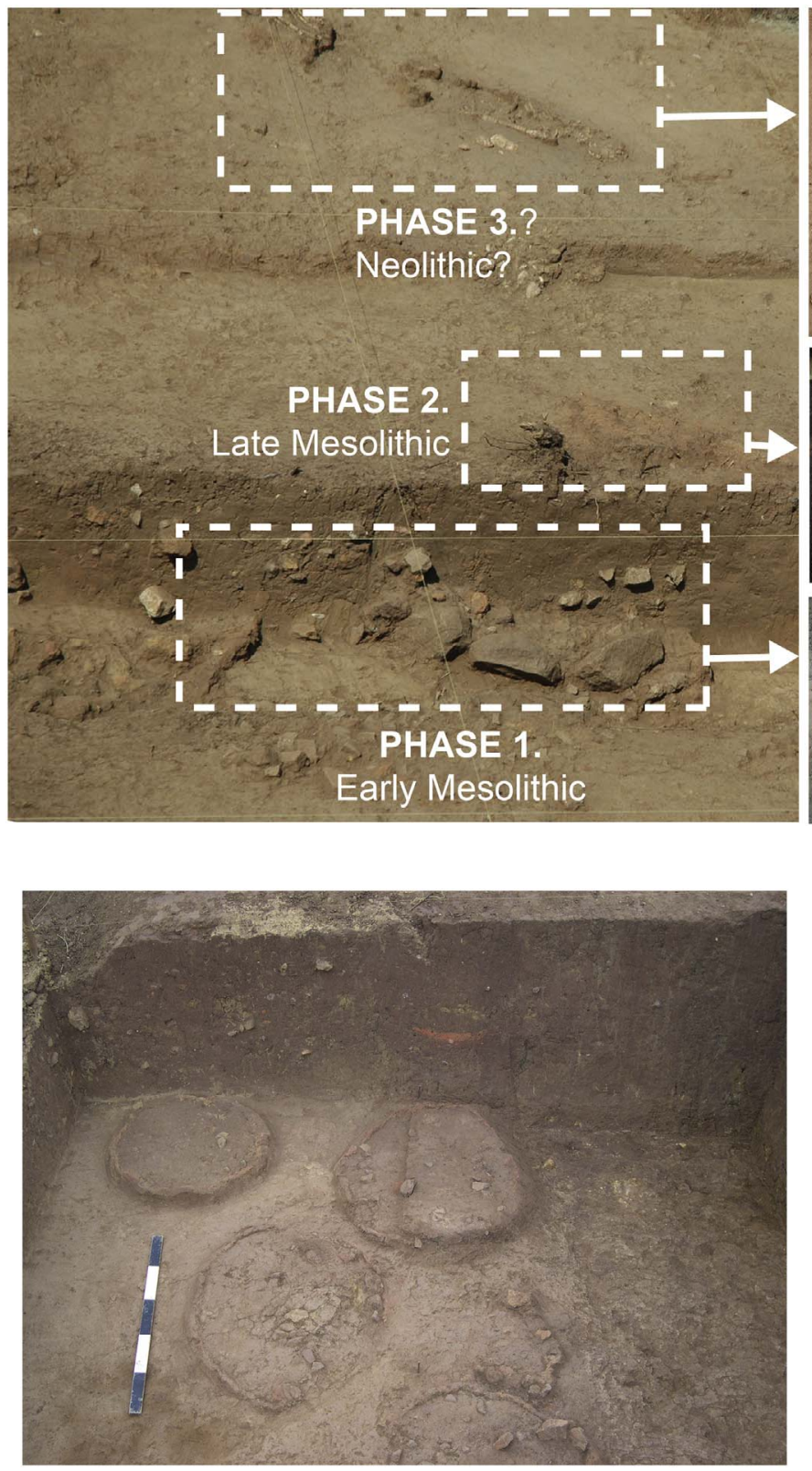

Fig. 8. Clay plate from phase 2 (S.U. 44) covering a set of clay structures from phase 1.

Table 1

Cova da Baleia structures.

\begin{tabular}{|c|c|c|c|c|c|}
\hline \multirow[t]{2}{*}{ Type } & \multirow[t]{2}{*}{ Description } & \multirow[t]{2}{*}{ Variety } & \multicolumn{2}{|c|}{ Phase } & \multirow[t]{2}{*}{ Num } \\
\hline & & & 1 & 2 & \\
\hline \multirow[t]{7}{*}{1 - CLAY } & 1.1. Pits or Kilns & 1.1.1. Domed & 18 & 2 & 20 \\
\hline & & 1.1.2. Tronco-conical & 9 & & 9 \\
\hline & & 1.1.3. Undetermined & 39 & & 39 \\
\hline & & 1.1.4. Clay-stone mixture & 9 & & 9 \\
\hline & 1.2. Slabs & & & 17 & 17 \\
\hline & 1.3. Undetermined & & 9 & 1 & 10 \\
\hline & & & & & 104 \\
\hline \multirow[t]{4}{*}{ 2- STONE } & 2.1. Stone pavements & & 3 & 4 & 7 \\
\hline & 2.2. Post hole & & & 4 & 4 \\
\hline & 2.3. Undetermined & & & 8 & 8 \\
\hline & & & & & 19 \\
\hline 3 - PITS & & & 5 & & 5 \\
\hline TOTAL & & & 92 & 36 & 128 \\
\hline
\end{tabular}

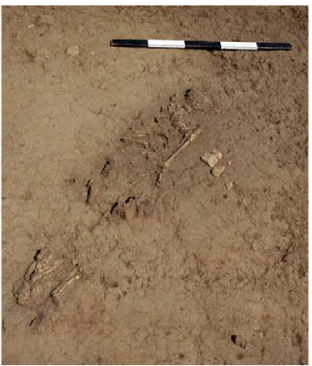

Fig. 7. Stratigraphic section of Cova da Baleia (West) with remains.

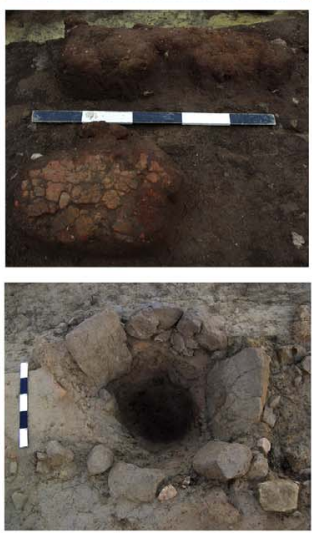

geometric armatures (Marchand et al., 2008), dominated by trapezoids (Diniz, 2013), a transverse arrowhead (Alday, 2006), some segments (Araújo, 2011), a back bladelet (Alday, 2006) and undeterminated armatures (Araújo, 2011).

The study of technology and raw materials has not yet been developed, although some trends are evident.

Pressure seems to be absent, with use of indirect percussion in phase 2 and direct use of soft hammerstone in phase 1.

In general terms, flint is dominant (85\%). The raw material seems to be of local acquisition, from Lower Estremadura, although some bladelet and geometric from phase 2 evidence a provenance of the Estremenho Limestone Massif. Also note the importance of quartz debitage (12\%) and the residual presence of quartzite, chert, siliceous rocks and hyaline quartz (Fig. 10, 11).

Only 68 pottery fragments were collected, four with decorations, two of which with cardial decoration. Ceramics are only at surface levels and are not associated with any phase 1 or 2 context.

\section{Functionality: methodological approaches in a different Mesolithic site}

The stratigraphy, structures, artefacts and radiocarbon dates allow us to confirm that this site differs from others in the region and in the Iberian Peninsula:

1) Location. Within an inland area, but most Early Mesolithic sites in this region, located very near the Atlantic Ocean, are connected to the exploitation of aquatic resources.

2) Dimension. The majority of contemporary sites are probably small camps. However, most sites present small excavated areas, which may influence our perception of their sizes. Cova da Baleia has a large excavation area $\left(500 \mathrm{~m}^{2}\right)$, and the whole of the site exceeds 2 ha.

3) Complexity. Cova da Baleia includes a high number of archaeological structures (128), 104 built with clay, mainly related with combustion. This is the largest and better preserved collection of Mesolithic burnt clay structures from prehistoric Western Europe

It was clear that an interdisciplinary approach was mandatory in 
1.

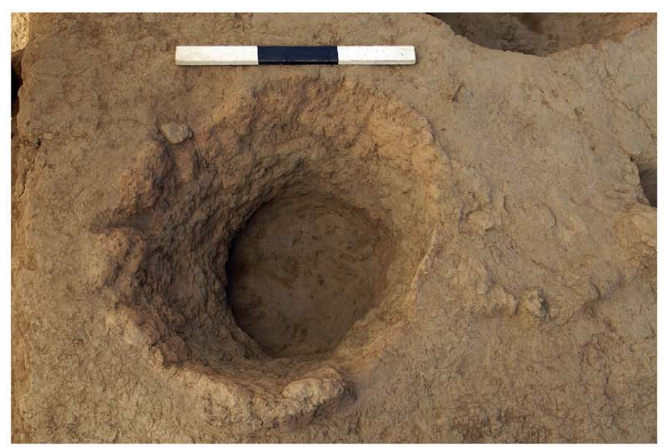

2.

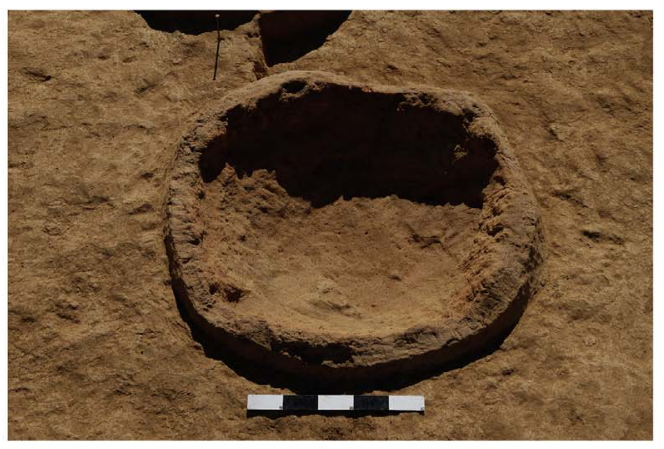

3,4 .

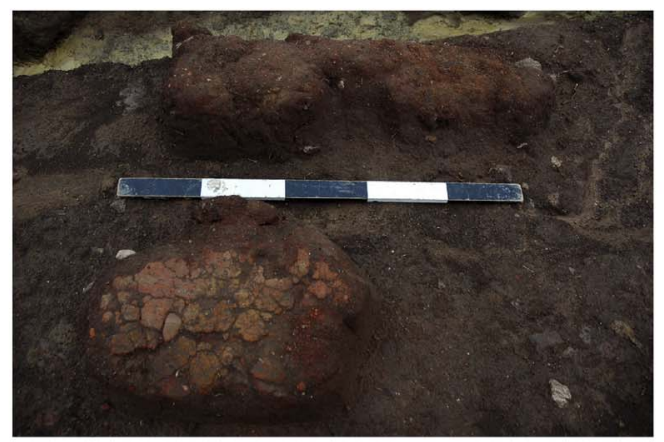

5.

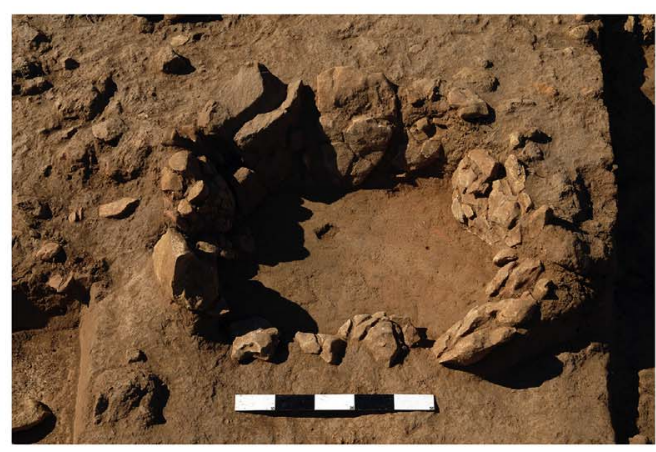

6.

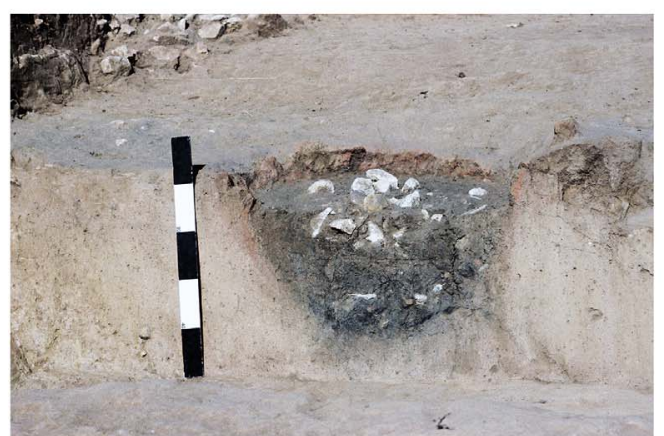

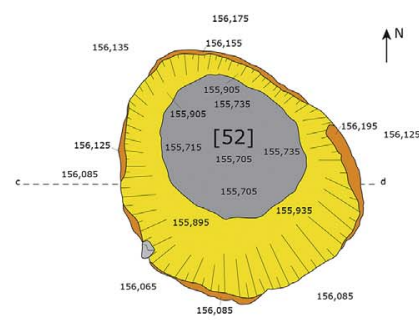

Cova da Baleia
[52]: Final Plan

Greywacke

$\square$ Clay (preserved top)

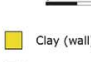

$\square$ Clay (wa)

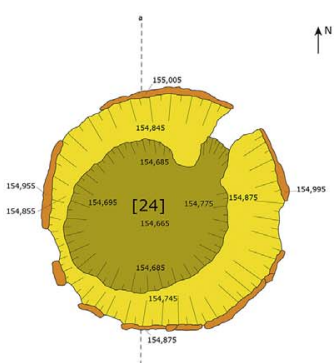

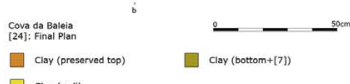

$\square$ clay (wall)
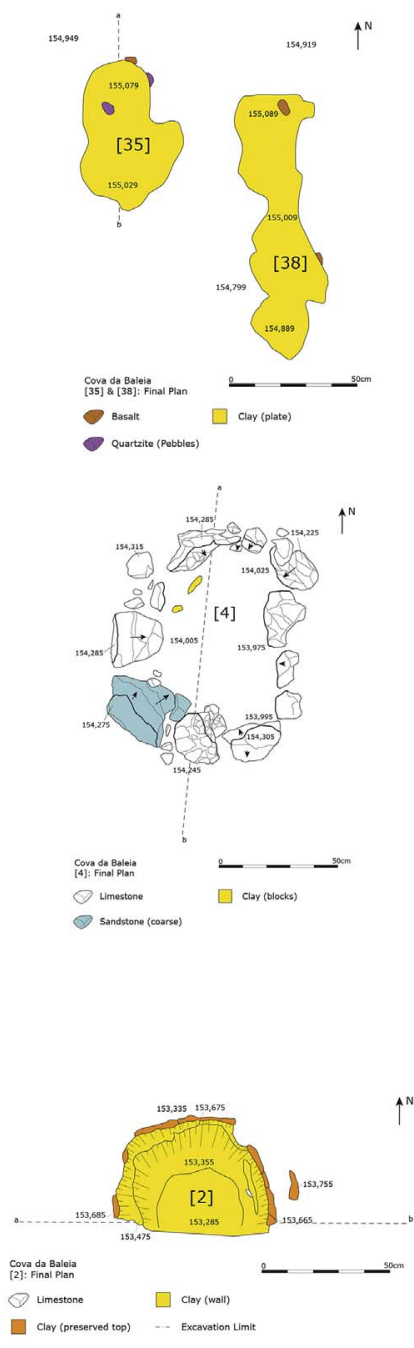

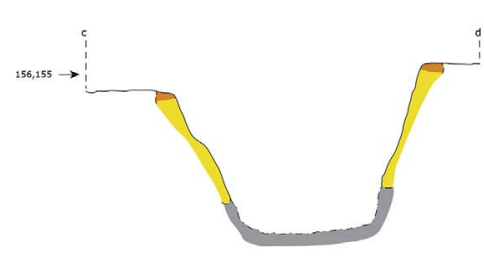

Cova da Baleia
[52]: Profile W-E

$\square$ Clay (preserved top) $\quad \square[1 \mathrm{~d}]$

$\square$ Clay (wall) $\quad$-.- Excavation limit

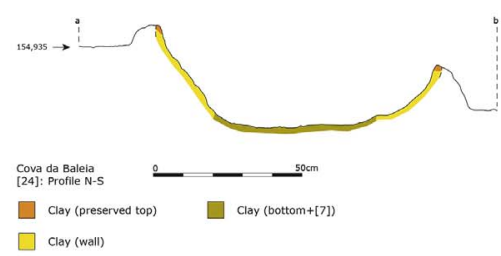

Cova da Baleia $50 \mathrm{~cm}$

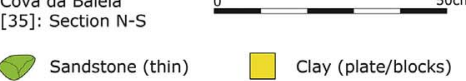

Quartzite (Pebbles)

-.. Excavation Limit

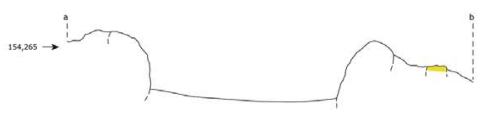

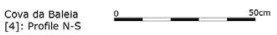

8 Umestone

$\square$ Clay (blocks) 


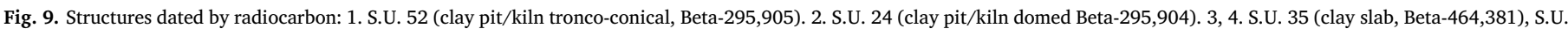
38 (clay slab, Beta-464,382). 5. S.U. 4 (clay pit/kiln domed, Beta-295,903). 6. S.U. 2 (clay pit/kiln domed, Beta-294,170).

order to fully guarantee the sites interpretation, namely regarding its functionality. Up to now, use-wear analyses and archaeobotanical analyses were carried out.

Use-wear analysis can help to infer some activities that were developed in the site. Allowing us to understand whether Cova da Baleia was a residential campsite or specialized in some activities related to the combustion structures. Considering that plant remains were the only residues derived from the use of the structures, an archaeobotanical study could provide information regarding the wood and other plant parts that were burned. Its direct relation to human activities could then be assessed.

The approaches will take into consideration the site phase, integrating the information with other indicators, such as the structure typology and material culture.

\subsection{Use-wear analysis of lithic tools from Cova da Baleia}

A traceological analysis was carried out on the flaked stone assemblage of Cova da Baleia, including 95 items from layers 1 and 2. The selection of this sample followed different criteria: morphometric and morphologic criteria, presence or absence of retouched edges, and preservation conditions.

Analysis was carried out using light microscopy: a stereoscopic microscope Leica MZ16A, with magnifications between $10 \times$ and $90 \times$ and a reflected-light microscopy Olympus BH2, with magnifications between $50 \times$ and $400 \times$, equipped with a Canon 450D camera. Micrographs taken at different focal positions were combined into a focus image using Helicon Focus v.4.62 (Fig. 12).

The state of preservation of the lithic assemblage is average. Most of the artefacts show a well-developed soil lustre, often in association with other modifications such as patinas and thermal alterations. Taphonomic modifications influence the conservation of the use-wear traces, especially traces produced by contact with soft materials, masked by such alterations. In some cases the presence of distinct patterns of edge-scarring allows the inference of the hardness of the worked materials. Despite such limitations, the information obtained on lithic tool-use provided a clearer picture of the technologic and functional behaviours of the Mesolithic groups that inhabited Cova da Baleia. The criteria involved in the choice of the blank for tool production, and the activities in which those tools were employed was identified, enhancing the knowledge of the economic organization of those groups.

The microscopic observation of the lithic tools allowed the identification of 49 used tools; 9 artefacts had not been used, 13 were too altered to be analysed, while 24 showed no diagnostic features to determine whether they were used or not. Considering the used tools, the first aspect to note is the intense exploitation of all the potential active zones: 20 of the 49 tools (40.8\%) show two active zones, while one tool shows three different active edges. Therefore, 49 tools correspond to 71
Table 3

Lithic industry of Cova da Baleia.

\begin{tabular}{|c|c|c|c|c|c|c|}
\hline & \multicolumn{2}{|c|}{ PHASE 1} & \multicolumn{2}{|c|}{ PHASE $1 / 2$} & \multicolumn{2}{|c|}{ PHASE 2} \\
\hline & $\mathrm{N}^{\circ}$ & $\%$ & $\mathrm{~N}^{\circ}$ & $\%$ & $\mathrm{~N}^{\circ}$ & $\%$ \\
\hline \multicolumn{7}{|l|}{ Cores } \\
\hline Cores & 66 & $8 \%$ & 275 & $11 \%$ & 73 & $8 \%$ \\
\hline Nodules & 0 & $0 \%$ & 2 & $0 \%$ & 2 & $0 \%$ \\
\hline \multicolumn{7}{|l|}{ Preparation } \\
\hline Tablette & 5 & $1 \%$ & 40 & $2 \%$ & 12 & $1 \%$ \\
\hline Core front & 13 & $2 \%$ & 32 & $1 \%$ & 7 & $1 \%$ \\
\hline \multicolumn{7}{|c|}{ Debris/knapping residues } \\
\hline Chunks & 363 & $45 \%$ & 900 & $36 \%$ & 363 & $42 \%$ \\
\hline Chips & 57 & $7 \%$ & 192 & $8 \%$ & 42 & $5 \%$ \\
\hline \multicolumn{7}{|l|}{ Debitage products } \\
\hline Bladelet & 26 & $3 \%$ & 112 & $4 \%$ & 3 & $0 \%$ \\
\hline Blade & 6 & $1 \%$ & 16 & $1 \%$ & 6 & $1 \%$ \\
\hline Flake & 203 & $25 \%$ & 637 & $25 \%$ & 271 & $31 \%$ \\
\hline \multicolumn{7}{|l|}{ Tools } \\
\hline Burin & 0 & $0 \%$ & 0 & $0 \%$ & 1 & $0 \%$ \\
\hline Denticulated & 0 & $0 \%$ & 10 & $0 \%$ & 4 & $0 \%$ \\
\hline Notches & 23 & $3 \%$ & 101 & $4 \%$ & 32 & $4 \%$ \\
\hline Perfurator & 0 & $0 \%$ & 2 & $0 \%$ & 3 & $0 \%$ \\
\hline Armatures & 0 & $0 \%$ & 15 & $1 \%$ & 3 & $0 \%$ \\
\hline Retouched bladelet & 1 & $0 \%$ & 24 & $1 \%$ & 3 & $0 \%$ \\
\hline Back Bladelet & 1 & $0 \%$ & 0 & $0 \%$ & 0 & $0 \%$ \\
\hline Retouched blade & 2 & $0 \%$ & 9 & $0 \%$ & 3 & $0 \%$ \\
\hline Retouched flake & 16 & $2 \%$ & 63 & $3 \%$ & 20 & $2 \%$ \\
\hline Microburin & 0 & $0 \%$ & 0 & $0 \%$ & 1 & $0 \%$ \\
\hline Scraper & 0 & $0 \%$ & 10 & $0 \%$ & 1 & $0 \%$ \\
\hline SNS & 23 & $3 \%$ & 67 & $3 \%$ & 13 & $2 \%$ \\
\hline Truncated bladelet & 0 & $0 \%$ & 0 & $0 \%$ & 2 & $0 \%$ \\
\hline Sub-total & 805 & $100 \%$ & 2507 & $100 \%$ & 865 & $100 \%$ \\
\hline
\end{tabular}

active zones.

Among the worked materials, the most recurrent are: dry hide, wood and bone materials (Fig. 13). Other contact materials, such as meat or non-ligneous plants, are little represented, while other soft substances, such as fresh hide or fish, are absent. Considering taphonomic modification, this type of material is probably underrepresented. Similarly, for 23 of the 71 active zones $(32,4 \%)$ only the hardness of the worked materials was inferred, while the exact type of substance has not yet been determined.

Most of the pieces are from layers 1 and 2. The material from the different levels is similar, so results will be explained globally. Only in specific cases will material from a specific level be referred.

Among the well conserved artefacts, only one tool showed traces associated with soft materials, in particular butchering activities: a fragment of an unretouched blade with edges around $20-25^{\circ}$. This type of blank, given the cutting effectiveness of its unretouched acute edges, is commonly used for butchering or slaughtering.

Table 2

Radiocarbon dates for Cova da Baleia.

\begin{tabular}{|c|c|c|c|c|c|c|c|}
\hline Laboratory reference & Sample reference & $\begin{array}{l}\text { Sample } \\
\text { type }\end{array}$ & Radiocarbon date (BP) & Calibrated $\mathrm{BP}^{\mathrm{a}}$ & Calibrated date $(2 \sigma)^{\mathrm{a}}$ & Phase & Structure type \\
\hline Beta-294,170 & CBL-L7-2-[2] & Charcoal & $8230 \pm 50$ & $9400-9020$ & $7450-7080$ & 1 & 1.1.1. \\
\hline Beta-295,903 & CBL-N7-[5] & Charcoal & $8460 \pm 50$ & $9420-9030$ & $7460-7080$ & 1 & 1.1.4. \\
\hline Beta-295,904 & CBL-R10-[24] & Charcoal & $8250 \pm 50$ & $9540-9420$ & $7580-7470$ & 1 & 1.1 .1 \\
\hline Beta-295,905 & CBL-W10 [52] & Charcoal & $8320 \pm 40$ & $9450-9250$ & $7500-7300$ & 1 & 1.1 .2$. \\
\hline Beta-464,382 & CBL-Q8-[38] & Charcoal & $8410 \pm 30$ & $9516-9329$ & 7567-7371 & $1 / 2$ & 1.2. \\
\hline Beta-464,381 & CBL-Q8-[35] & Charcoal & $7330 \pm 30$ & 8191-8035 & $6242-6086$ & 2 & 1.2. \\
\hline
\end{tabular}

a According to the calibration curves IntCal13 (samples of the terrestrial biosphere) of Reimer et al. (2013), and using CALIB rev 13.0 (Stuiver and Reimer, 1993). 

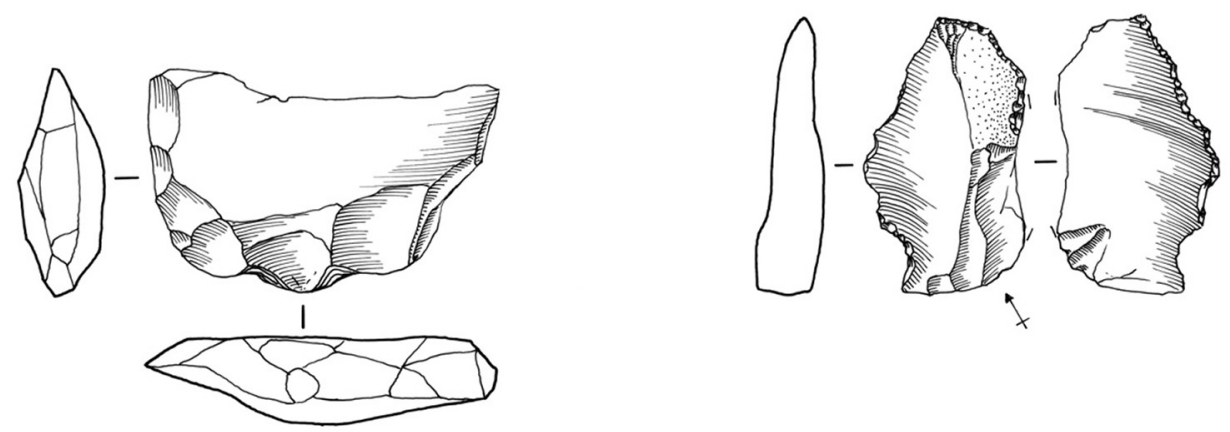

Fig. 10. Lithic industry (flakes and notches) from phase 1 (Early Mesolithic).
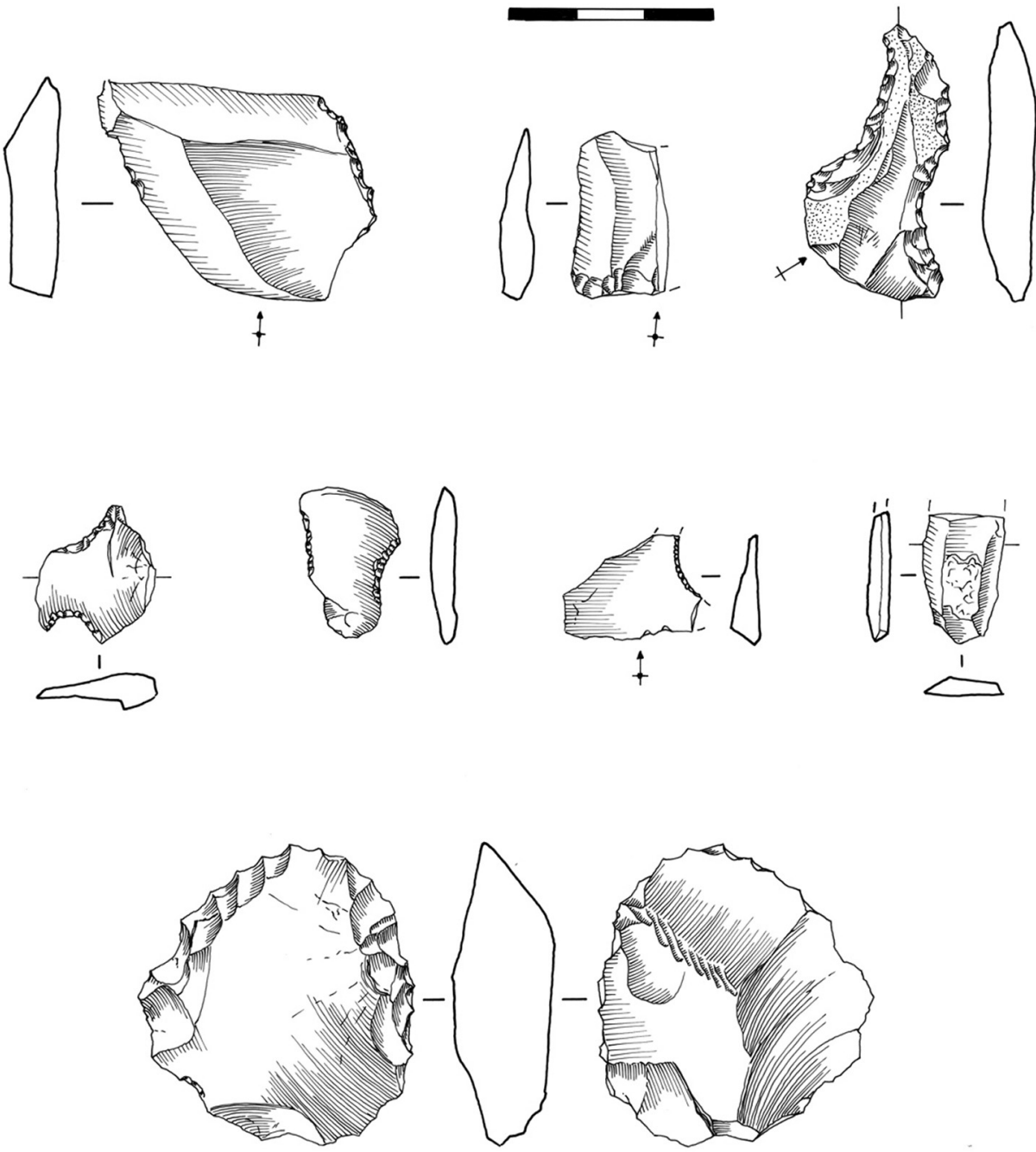

Tools used for working dry hide were made on flakes and blades, with edges retouched to form a notch, or slightly denticulated edges. Edge retouching would have served to reduce its sharpness, in order to avoid cuts and scratches on the worked hide. Moreover, retouched edges tend to be more resistant and durable, and are especially suited for working abrasive substances (Fig. 13: 1).

Active zones are always quite small, partly due to the reduced size of the flaked blanks. However, the type of active zones and their length suggests that their main tasks were resharpening or finishing. Other tasks, (i.e. hide hair removal and fleshing) involving tools with larger active zones were maybe carried out with wood, bone or macrolithic tools. Among the used tools, only two flakes show more developed traces possibly associated with hide treatment; both show a highly rounded edge, characterized by several fine striations. This type of wear suggests that hides (or some other soft substance) were worked with some type of abrasive additive, although we can't exclude they were used to scrape a soft mineral (these two pieces are precisely from level 2).

Several tools used for working bone were also identified. Used blanks are flakes, retouched to form one or more notches (Fig. 13: 3-4). Notches were used to scrape bone materials and, as observed for hidescraping tools, active zones are slightly extended, between 5 and $10 \mathrm{~mm}$ in length, suggesting the performed tasks were mainly for repairing or finishing bone objects, such as bone punches or points, thus relatively 

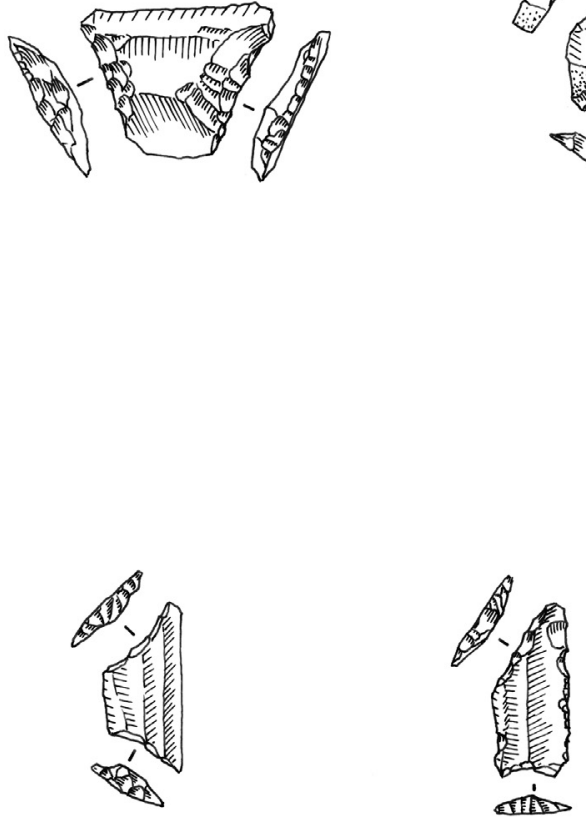
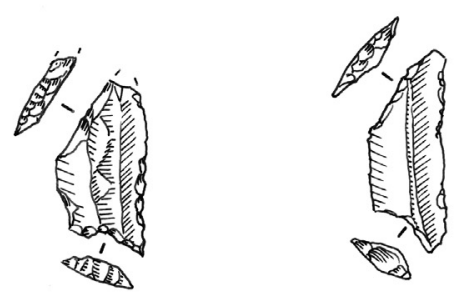

Fig. 11. Lithic industry (geometric armatures) from phase 2 (Late Mesolithic)
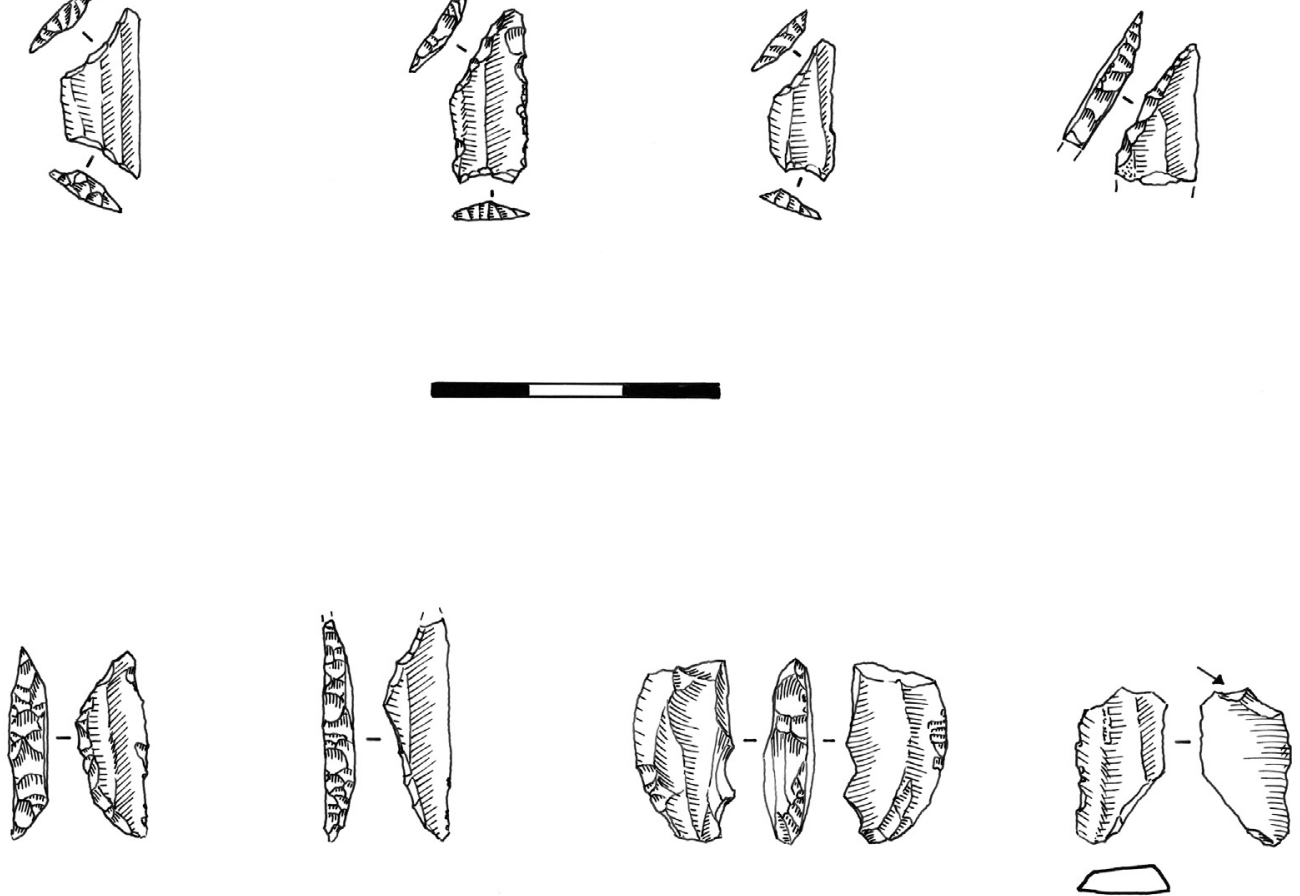

specialized tasks.

Tools used for working wood are morphologically and functionally very similar: retouched blanks, with notches or with more or less continuously retouched edges (typologically corresponding to sidescrapers or denticulated tools; Fig. 13: 2). Several active zones were used for each blank, each between 5 and $20 \mathrm{~mm}$ on length. Tools were used for scraping, probably to repair or resharpen wooden objects.

In addition, other tools with poorly conserved traces probably related to plant matter were identified. One tool was used for cutting some type of plant (level 2), while several tools (6 tools with 8 active zones) were used for scraping plants or wood. The former is an unretouched blade, while the latter are retouched blades or flakes, with denticulated edges and/or notches.

Other tools ( 5 tools with 7 active zones), characterized by a lower conservation of the use-wear traces, were also used to work some type of resistant material, whose nature could not be inferred. However, their technological and functional characteristics are very similar to those described above for bone and wood scraping tools.

Finally, 16 tools, corresponding to 23 active zones, could not be attributed to any of the above-mentioned categories, as the observed use-wear traces are too altered to be correctly interpreted. Nevertheless, their technological and functional characteristics are in line with those described above, with the sole exception of two unretouched blades probably used for cutting soft substances. The rest of the tools present the same features as flakes and blades used for scraping hide/wood/ bone.

In conclusion, the traceological analysis of the Cova da Baleia assemblages has formed a clearer picture of the technological and functional behaviours of the Mesolithic groups that inhabited the site. The results are particularly interesting considering that hide, wood and bone materials are often not well conserved in Portuguese prehistoric deposits. The information provided by the use-wear analysis is, thus, particularly important, providing information on activities that otherwise would go unperceived in the archaeological records. Hide, bone and wood artefacts were probably an important part of the Early Mesolithic crafts. Unfortunately, the poor conservation of the collection has prevented the recognition of other classes of materials, such as soft animal substances and fresh hide. Butchering, slaughtering and raw- 


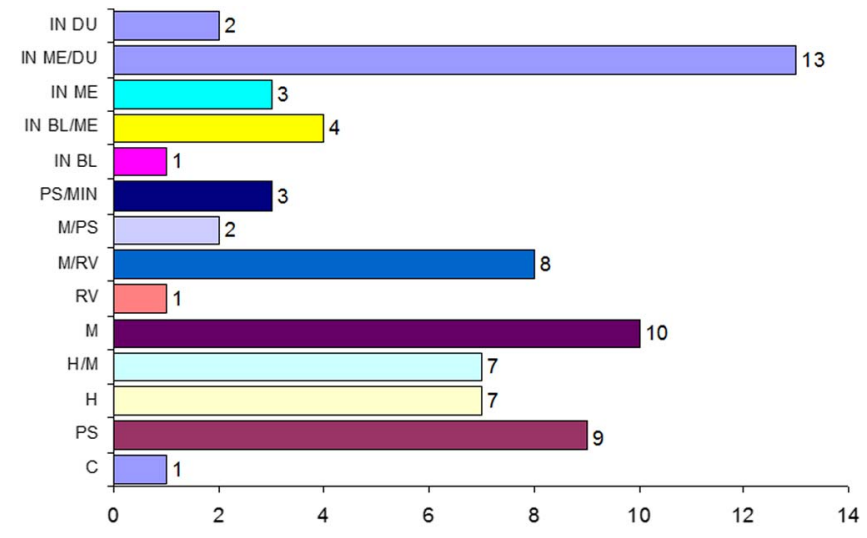

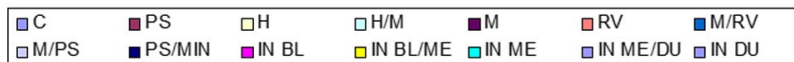

Fig. 12. Total active zones: $\mathrm{C}=$ Butchering, $\mathrm{PS}=$ Dry Hide, $\mathrm{H}=$ Bone, $\mathrm{H} / \mathrm{M}=$ Bone or Wood, $\mathrm{M}=$ Wood, $\mathrm{RV}=$ Plants, $\mathrm{M} / \mathrm{RV}=$ Wood or Plants, $\mathrm{M} / \mathrm{PS}=$ Wood or Dry Hide, $\mathrm{PS} / \mathrm{MIN}=$ Dry Hide or Mineral, IN BL = Indeterminate Soft, IN BL/ME = Indeterminate Soft or Medium Hard, IN ME = Indeterminate Medium Hard, IN ME/ DU $=$ Indeterminate Medium Hard or Har, IN DU = Indeterminate Hard.

hide treatment activities were probably underrepresented in the analysed sample.

The results also provide insights into the Cova da Baleia group's cultural and technological affiliation. Creating notches on blades or flakes in order to scrape a variety of materials is a common behaviour among Mesolithic groups. In the Iberian Peninsula there are several similar cases in which flakes and blades were retouched through notches and used for working a wide array of materials such as wood, hide and bone, including layer IV in Bauma del Serrat del Pont (Gibaja, 2008), layer IV in Mendandia (Alday, 2006; Mazo, 2006; Mazzucco et al., 2016), Roc del Migdia (Rodríguez, 1993) and Barca do Xerez de Baixo (Igreja, 2013). All those tools are characterized by a very similar use pattern: edges are employed for brief tasks, often using several active zones for each artefact. Tasks appear related to very specific stages of wood/bone/hide artefacts manufacturing and/or maintenance, a sort of multi-task tool employed in a variety of crafting and manufacturing processes.

The present functional study constitutes a first approach to this thematic. In the future, it will be necessary to increase the sample and to make a three-dimensional analysis of the lithic industry.

In spite of this, the importance of the work of wood and non-woody plants, possibly related to the function of structures, should be emphasized. Detection work related with meat processing may have been affected by changes in the surface of parts.

The scarcity of indicators related to hunting may have an explanation either taphonomic or functional. The hypothesis of the use of projectiles made of bone or wood can be advanced, which has not been preserved for taphonomic reasons. For Toledo, a concheiro situated in the same region as Cova da Baleia, it is "les esquilles ont dû effectivement servir de petites barbelures d'armes composites (armées latéralement), dont les pointes (l'extrémité perforante) devaient être fabriquées en bois". (Araújo, 2012, p. 355).

It can also be advanced that Cova da Baleia would be a specialized site with little representation of the game.

The apparent lack of tools related hunting contrast with the lithic industry in other sites with abundant clay ovens, as the sites of Baixa do Xarez (Gonçalves et al., 2013) or Defesa de Cima 2 (Santos and Carvalho, 2008; Diniz, 2013), where the tools is dominated by the presence of armatures, namely trapezoids. Only a detailed study was carried out for the lithic industry of Xarez 12 (Gonçalves et al., 2008, 2013), showing the importance of the micro-laminar industries to obtain geometric armatures on local raw materials, which seems to support an interpretation of the site associated with hunting, also shown by the fauna study (Cardoso, 2013). For Defesa de Cima 2, quantitative data are not available, but the presence of notches and scrapers is mentioned, as in Cova da Baleia (Diniz, 2013, p. 325).

\subsection{Paleobotanic analysis}

During field work, the sampling strategy combined handpicking of large charcoals, with the collection of sediment samples (varying from 4 to 6 l) from each structure. Up to now, 39 handpicked samples and 18 sediment samples from 22 structures and five from other contexts have been studied.

An attempt to recover plant remains through wet sieving and flotation failed, as it was noticeable that charcoal remains would disintegrate in contact with water, preventing the taxonomic diagnosis. This was the experience in a previous study by Arranz-Otaegui (2016). This author explored the causes of wet sieving and the consequences for charcoal identification, demonstrating that water may damage charcoal fragments. Differential preservation can have severe impact upon the final results and context interpretation, leading to a distortion of actual diversity.

The samples from Cova da Baleia were sorted, but no carpological remains were retrieved. Charcoal fragments were studied following a standard methodology, where the three diagnostic sections (transverse, radial and tangential) were obtained manually and observed under a stereomicroscope (Nikon SMZ800) and a reflected-light microscope (Nikon Eclipse 50i), and identifications were supported by wood anatomy atlases (Schweingruber, 1990, Vernet et al., 2001). Only charcoal fragments larger than $2 \mathrm{~mm}$ were analysed. Dendrological and taphonomical characteristics, such as ring curvature, vitrification, radial cracks and biological deterioration, were noted (e.g. Mcparland et al., 2010, Théry-Parisot and Henry, 2012).

\subsubsection{Results}

Taxonomic identification revealed a low biodiversity (Table 4). In a total of 2484 fragments analysed (see Supplementary Material), Fraxinus sp., Quercus spp. (including both deciduous and evergreen) were the only taxa identified. As such, no relevant differences were detected between different structures and other contexts. Notably, there was a high percentage of "Dicotyledon" and "Undetermined" fragments (almost 75\%). Further detailed identification was not possible due to the poorly preserved diagnostic features. Vitrified charcoal was observed repeatedly (84\%) and, to a lesser extent, radial cracks (almost 30\%). Ring curvature, mainly weak, was only noticeable in a fifth of the studied fragments.

Results from the previous study of three samples (Queiroz, 2013) revealed the presence of eleven fragments of Olea europaea, four of Quercus sp. and an Undetermined fragment. These results bring an additional species to the diversity found in this study.

Diversity was consistently low in the analysed structures. Charcoal assemblage in the clay structures (77 samples analysed) was richer than other structures. Deciduous Quercus were differentiated from evergreen Quercus, as well as Fraxinus sp. from Quercus sp. Dicotyledons were always the major taxa in the remaining structures, and the results were very homogeneous.

Quantitative results were highly biased by the preservation state of the fragments. The size of the fragments was generally small, but some pieces handpicked in the field were considerably large (up to $14 \times 10 \times 4 \mathrm{~cm}$ ), because the clayish sediment helped maintain the charcoalified wood pieces together. These were exclusively deciduous Quercus (Fig. 14). Thus, although Fraxinus sp. is more frequent, there is a higher volume of deciduous Quercus. Conversely, Fraxinus was recovered in many more contexts, suggesting it was, in fact, the most recurrent taxon used as fuel. Notwithstanding, palaeoecological deductions from the data were not possible. Primary contexts, such as kilns and ovens, represent single events of selection and use of firewood 


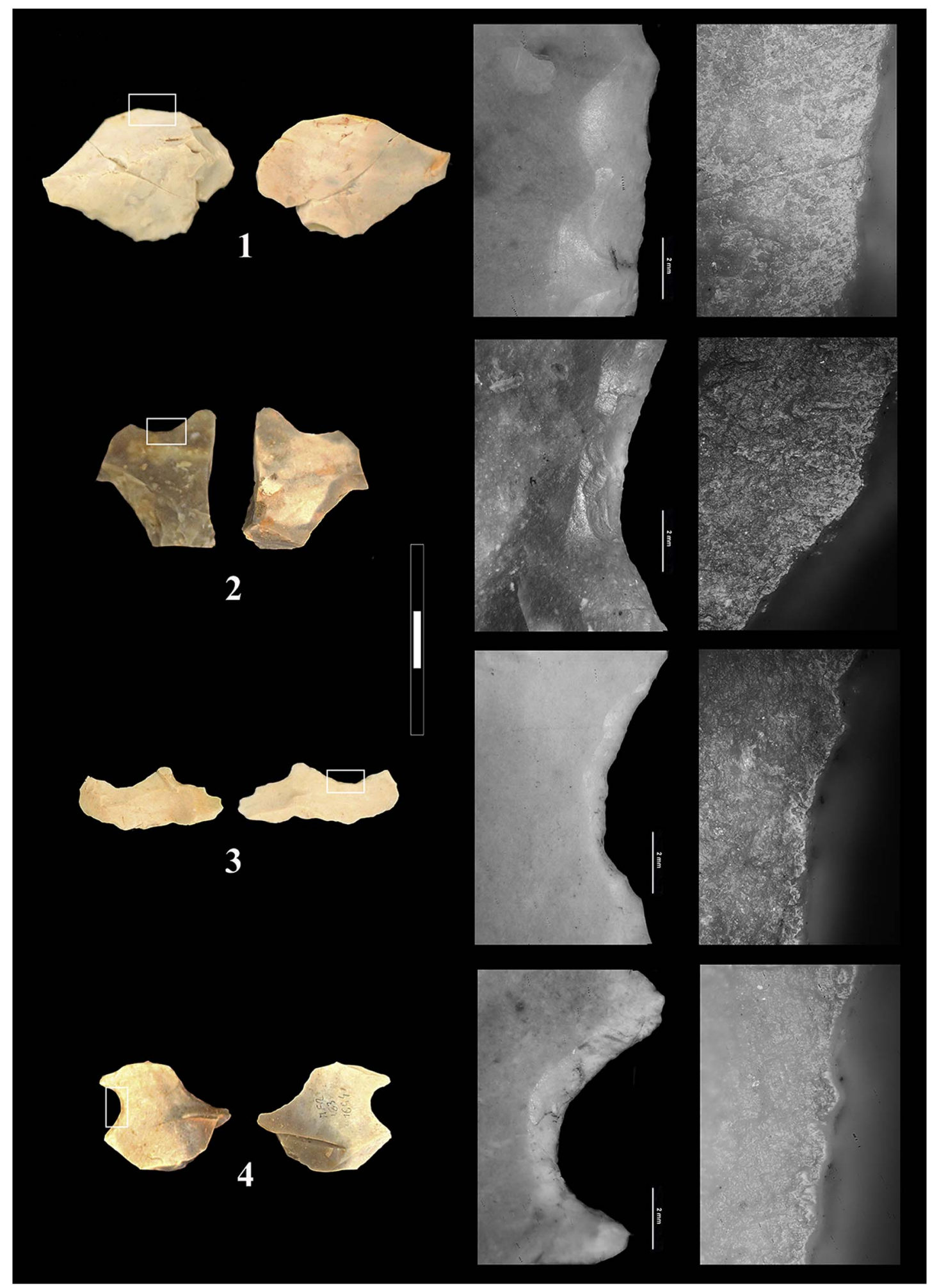

Fig. 13. 1. Scraping Dry Hide (MFR.183-1926); 2. Scraping wood (MFR.183-1671); 3 and 4 Scraping bone (MFR.183-1672 and 1694). Microscope photo 200 × .

and, as such, are not suitable for palaeoecological approaches. Still, they document the presence of some species in the catchment area of the site.

Today, Fraxinus angustifolia is a rather common species in the region. Deciduous and marcescent species of Quercus in the region are mainly Quercus faginea and Quercus robur. The latter is rare, although we cannot exclude it was more frequent in the Early Holocene. Evergreen species are mostly Quercus ilex subsp. ballota (= Quercus rotundifólia), Quercus suber and Quercus coccifera. Deciduous Quercus and Fraxinus sp., the most common taxa in the samples, part of the climacic vegetation of the area and probably common in the Early Holocene. Palinological data from the river Sizandro valley (Torres Vedras) (Dembeck et al., 2015) revealed a dense forest cover until 5000 BCE, dominated by Quercus robur-type pollen (i.e. Quercus deciduous), Pinus pinaster-type and some riparian taxa like Alnus, Fraxinus and Salix, to name a few. Such is consistent with the proximity of the 
Table 4

Charcoal assemblage by context. Ubiquity was calculated by context and structure ( $n=$ number of structures).

\begin{tabular}{|c|c|c|c|c|c|c|}
\hline \multirow[b]{2}{*}{ Species } & \multicolumn{3}{|c|}{ Structures } & \multicolumn{3}{|c|}{ Ubiquity (\%) } \\
\hline & Clay & Stone & Other & $\begin{array}{l}\text { Clay } \\
(n=19)\end{array}$ & $\begin{array}{l}\text { Stone } \\
(n=3)\end{array}$ & $\begin{array}{l}\text { Other } \\
(n=5)\end{array}$ \\
\hline Fraxinus sp. & 368 & 28 & 30 & 78,9 & 100,0 & 60,0 \\
\hline Deciduous Quercus & 30 & & & 10,5 & & \\
\hline Evergreen Quercus & 2 & & & 5,3 & & \\
\hline Quercus sp. & 138 & 50 & 11 & 73,7 & 100,0 & 40,0 \\
\hline Dicotyledon & 1231 & 229 & 112 & 94,7 & 100,0 & 80,0 \\
\hline Undetermined & 224 & 19 & 12 & 89,5 & 100,0 & 80,0 \\
\hline Total & 1993 & 326 & 165 & & & \\
\hline
\end{tabular}

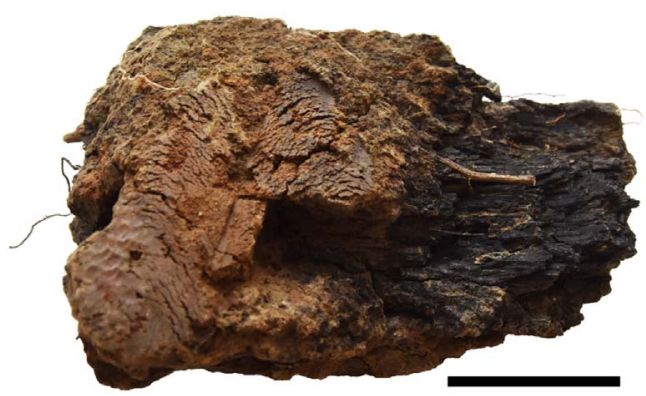

Fig. 14. Quercus deciduous fragment (Scale: $5 \mathrm{~cm}$ ).

sampling sites to the river. The palynological record confirms the regional presence of the taxa identified in the anthracological study of Cova da Baleia.

Other anthracological studies were conducted in coastal Mesolithic sites, such as Ponta da Vigia and the shell midden of São Julião. At Ponta da Vigia, Pinus pinaster (and other undetermined Pinus) was retrieved from three combustion structures (Zambujo and Lourenço, 2002), while at S. Julião a wide variety of taxa was recorded (Queiroz and van Leeuwaarden, 2004), comprising woody and shrubby species, both thermophilous and mesophilous, representative of Early Holocene environmental changes. These studies, together with that of Cova da Baleia, illustrate the variability of antracological results and highlight the specific character of each site in terms of firewood gathering. The reasons for the differences detected in the charcoal assemblages of the three sites are unknown. Environmental factors related to the surroundings of each site, the specific characteristics of the structures found in each site (clay ovens and kilns in Cova da Baleia, open hearths in the other two sites), could correspond to different functions, leading to the collection of different species for fuel. Firewood selection was determined by cultural reasons, varying among communities, which are difficult to address through the archaeological record, cannot be excluded.

\section{Discussion}

Integrating the data presented above, some questions persist regarding the occupation morphology in Cova da Baleia. The specific function of the location, residential or part of a logistic mobility model, is still unclear. Some elements seem to points out to the specific character of the occupation: the reduced density of archeologic materials, the near exclusive presence of fire structures, the dominant use of tools for working hides, wood and bone.

In addition, there is evidence of debitage, with all the stages of the châine operatoire, which contrasts with short duration logistic locations, such as the shell middens in São Julião (Sousa and Soares, 2016) or Pedra do Patacho (Silva and Soares, 2016), with the same chronology.
The central issue, naturally, is the functionality of such a large number of fire structures. In the first phase of occupation, 75 clay kilns were quantified. Although more absolute dates are necessary, we can generically include these ovens within a chronologic period between 7500 and $7000 \mathrm{cal} \mathrm{BCE.}$

The high number of ovens may indicate a dynamic repeated use of the location. Ethnoarcheologic studies conducted in the Ivory Coast among the Kouya community provide evidence for the ephemeral character of these structures and their successive repair and construction (Ramseyer, 2003). In Colombia, in San Jacinto 1, a site similar to Cova da Baleia was detected, with 112 ovens, concentrated in a $346 \mathrm{~m} 2$ area, in a context of transition from hunter-gatherer to producer societies (Stahl and Oyuela-Caycedo, 2007). In Cova da Baleia, several clusters of structures that may indicate successive episodes of occupation, including overlapping structures, can be identified.

Given the abundance of charcoal and thermally altered stones in the Cova da Baleia structures, the function was evidently related with combustion. Other interpretations were made elsewhere. At Defesa de Cima 2 (Évora) several pits were found, previously coated with clay and afterwards hardened by fire, with some resemblance with Cova da Baleia (Diniz, 2013). Based on ethnographic parallels with communities in North Africa (Carvalho e Santos, 2008), the archaeologists responsible for the excavations claim these pits were used for storage. However, given the undeniable presence of signs of combustion in all structures, and the absence of evidence of storage (seeds, for example), this hypothesis does not seem plausible.

The culinary function of similar ovens at Xarez 12 (Reguengos de Monsaraz, Évora), is evident considering the presence of faunal remains (Gonçalves et al., 2013), resulting from hunting activities (Bos primigenius, Sus scrofa) and mollusc collection (Unio). In Cova da Baleia, there are some bones, teeth and shells from the second phase of occupation; however from the first phase of occupation, from the Early Mesolithic, nothing was preserved. Although the limestone substrate is favorable for animal preservation, taphonomic reasons may account for the absence of fauna, a hypothesis to be developed in future studies.

Besides the preparation of meat, testified at Xarez 12, it is possible that such kind of structures were also used for preparing vegetables, for instance for cooking tubers. The archaeobotanical analysis only the identification of wood charcoal. No carpological remains or other kind of plant remains that could have been consumed by the Mesolithic human communities were recovered. Traditionally, there are preservation problems specific to these kind of remains and only seldom are they found in archaeological sites. Such plant parts are less resistant to fire than wood and their carbonization is usually accidental, thus occasional. Although the Portuguese sites present poor preservation of archaeobotanical remains, in the Colombian site of San Jacinto 1, exhibiting structures very similar to those in Cova da Baleia, the main function of the ovens was associated with processing plant species (Stahl and Oyuela-Caycedo, 2007). In l'Essart, a French mesolithic habitat with a vast excavation (Marchand et al., 2007, 2008) were also identified intense signs of fire-related activities in a vast area. Due to the presence of structures 39 and intense combustion fire signals in lithic materials is proposed that Essart l'corresponds to a site with a specific function, not yet documented in the west of France (Marchand et al., 2008, p. 107), with functions related to the smoking of fish and game.

The typological diversity of the structures (domed, tronco-conical, clay-stone mixture) and their dimensions are not yet understood. There are shallow, very broad structures $(1.2 \mathrm{~m} \times 0.40 \mathrm{~m})$ and others that are smaller and deeper $(0.50 \times 0.60 \mathrm{~m})$. In ethno-historic studies developed in Taiti, M. Orliac compiled historic records from the 18th century indicating that the type, size and form of the Polynesian ovens were different according to the type of products cooked, whether a dog, bird or vegetable (Orliac, 2003). In addition, each structure may have had multiple functions, within the functional limits imposed by its characteristics. 


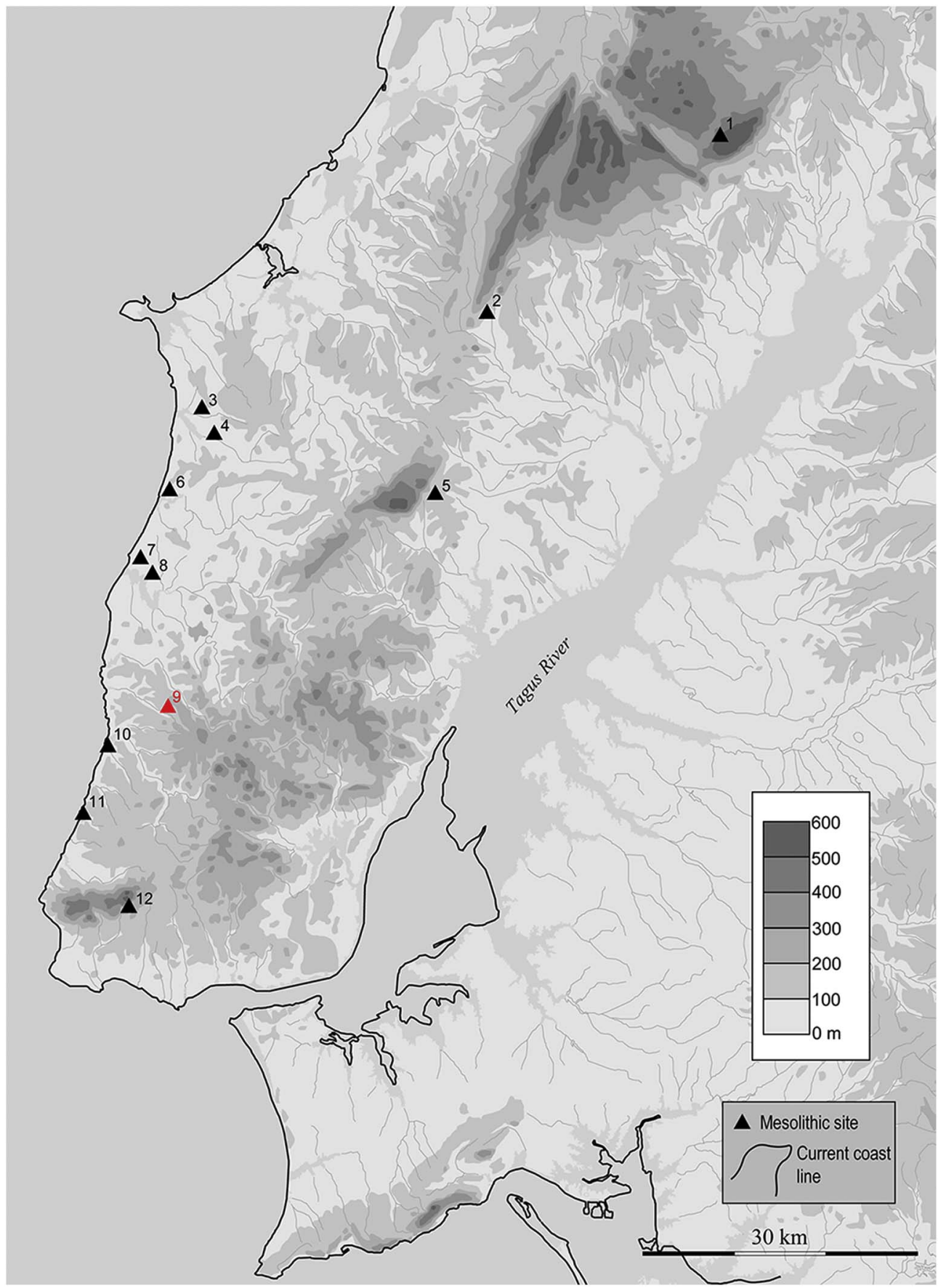

Fig. 15. Early Mesolithic in Central Portugal (Estremadura): 1- Lapa do Picareiro, 2 - Areeiro 3, 3 - Vale Frade, 4 - Toledo, 5 - Camarnal, 6 Ponta da Vigia, 7 - Curral Velho; 8 - Pinhal da Fonte, 9 - Cova da Baleia, 10 -São Julião, 11 Magoito, 12 - Penha Verde.

The results of the use-wear and archaeobotanical studies indicate the importance of wood and other hard materials, while the need for fire for these activities remains to be understood.

\section{Conclusion}

In the present Portuguese territory, Cova da Baleia is the first «oven» site that provides absolute dates. Xarez 12 and Carraça 1 did not present organic matter. The other sites (Lajinha 8, Defesa de Cima, Atafonas) don't have radiocarbon dates yet.

The identification of a new site typology for the Iberian Peninsula Mesolithic changes the scenario of settlement network in the Early Holocene, whose paradigm is centered upon shell middens. The function of these structures is yet to be ascertained, perhaps with many uses within a site and among regions.
Given the Early Mesolithic chronology and the specificity of the occupation, there may have been a marked seasonality and relatively wide area of exploitation, eventually associated with aquatic resources. In a nearby area and with a similar chronology, remains the shell middens in São Julião $(18 \mathrm{~km})$ and Magoito $(25 \mathrm{Km})$. Considering the relative ease of building structures such as these, there seems to be no contradiction between settlements of gatherers with high mobility that invest in the construction of domestic, albeit temporary, structures (Fig. 15).

Future supplementary studies may provide more information in order to understand Cova da Baleia, such as the archaeometric study of the clays and residues from the ovens, the provenance of raw materials, geo-archeologic and micro-morphology studies to understand the depositional processes larger traceologic samples, and tri-dimensional analyses. 
Extending the diachronic reading of the site would also be important. Only in the second phase of the site are there some structures of another type, namely postholes and stone pavements, perhaps indicating the presence of residential structures. The lithic industry also reveals changes. The essential function may plausibly have remained generically the same, related with the functionality - yet unknown - of the fire structures. Cova da Baleia notably presents a profusion of ovens from several epochs: a mere $50 \mathrm{~m}$ away, there are three ovens for the production of tiles dated to the Roman, Medieval and Modern periods. The same functions were therefore generically maintained in the area.

To further the functional interpretation of this type of site, additional systematic studies such as those performed in Xarez 12 (Gonçalves et al., 2013) and now Cova da Baleia need to be performed in other sites.

Mafra, Lisboa, Porto, Barcelona. Spring, 2017.

\section{Acknowledgement}

The archaeological field works were supported by the Council of Mafra and Mafratlântico. The study of the material culture was founded by the project "Earth, Water, Air, Fire. Cova da Baleia in the Iberian Early Mesolithic" (The Archaeology of Portugal Fellowship - 2012, Archaeological Institute of America), directed by Ana Catarina Sousa. The radiocarbon dates have been funded by UNIARQ - WAPS, Centre for Archaeology Lisbon University and Workgroup on Ancient Peasant Societies (UID/ARQ/00698/2013).

The traceological study has been realized in the framework of the research projects: "La difusión del neolítico en el Mediterráneo centro-occidental: agricultura, innovaciones tecnológicas y carbono 14 (HAR201675201-P)" funded by the Spanish Ministry of Economy and Competitiveness and directed by J. F. Gibaja and "Le temps des moissons: l'arrivée des premières communautés d'agriculteurs en méditerranée centrale" funded by the Maison Archéologie \& Ethnologie (MAE 2016) and directed by N. Mazzucco.

The translation to English was made by André Levy and Maria Manuel Bringel. The drawings were made by André Pereira (structures) and Fernanda Sousa (lithics).

\section{Appendix A. Supplementary data}

Supplementary data to this article can be found online at https:// doi.org/10.1016/j.jasrep.2017.10.049.

\section{References}

Alday, A., 2006. El legado prehistórico de Mendandia: los modos de vida de los últimos cazadores-recolectores en la prehistoria de Treviño. In: Arqueología de Castilla y León, (Memorias 15).

Araújo, A.C., 2011. O concheiro de Toledo no contexto do Mesolítico Inicial do litoral da Estremadura. In: Lisboa: IGESPAR (Trabalhos de Arqueologia, 53), pp. 255.

Araújo, A.C., 2012. Une histoire des premières communautés mésolithiques au Portugal, thèse de doctorat, université. Paris 1 - Panthéon-Sorbonne, pp. 420.

Araújo, A.C., Moreno García, M., Gabriel, S., 2014. Para além de Toledo. Outros dados, novas revisões e algumas reflexões sobre o Mesolítico antigo do litoral da Estremadura. Rev. Port. Arqueol. 17, 5-34.

Arranz-Otaegui, Amaia, 2016. Evaluating the impact of water flotation and the state of the wood in archaeological wood charcoal remains: Implications for the reconstruction of past vegetation and identification of firewood gathering strategies at Tell Qarassa North (south Syria). Quat. Int. 57, 60-73 ISSN 1040-6182.

Bicho, N.F., 1994. The end of the Paleolithic and the Mesolithic in Portugal. Curr. Anthropol. 35 (5), 664-674. http://dx.doi.org/10.1086/204328.

Bicho, N.F., 2000. Technological Change in the Final Upper Paleolithic of Rio Maior. Instituto Politécnico, Tomar (Arkeos 8).

Cardoso, J.L., 2013. Xarez 12. Estudo arqueozoológico de mamíferos. In: Gonçalves, V.S., Sousa, A.C., Marchand, G. (Eds.), Na margem do Grande Rio. 1. Os últimos grupos de caçadores-recolectores e as primeiras sociedades camponesas no baixo Guadiana. Évora: DRCALEN/EDIA, pp. 559-569.

Dembeck, Rainer, Kunst, Michael, Heinrich, Thiemeyer, Kalis, Arie J., van Leeuwaarden, Win, Herrmann, Nico, 2015. Onde é que habitaram? Novos dados sobre a Neolitização retirados do exemplo do Vale do rio Sizandro (Torres Vedras, Portugal). In: Gonçalves, V.S., Diniz, M., Sousa, A.C. (Eds.), $5^{\circ}$ Congresso do Neolítico Peninsular. UNIARQ, Lisboa, pp. 385-396. http://hdl.handle.net/10451/28060.
Dias, J.A., 2004. A história da evolução do litoral português nos últimos vinte milénios. In: Tavares, A.A., Tavares, M.J.F., Cardoso, J.L. (Eds.), Evolução Geohistórica do Litoral português e fenómenos correlativos: geologia, história, arqueologia e climatologia. Universidade Aberta, Lisboa, pp. 157-170.

Diniz, M., 2013. Fossas, fornos, silos e outros meios de produção: acerca da implantação das práticas produtivas no Neolítico antigo em Portugal. In: Arnaud, J. Morais, Martins, Andreia, Neves, César (Eds.), Arqueologia em Portugal: 150 anos. Associação dos Arqueólogos Portugueses, Lisboa, pp. 319-328. http://hdl.handle. net/10451/10659.

Gaspar, R., Pedro, J., Mata, J., 2009. Estudo arqueopetrográfico da utensilagem lítica do sítio neolítico da Lajinha 8 (Évora). Rev. Port. Arqueol. 12, 19-33 (Lisboa). (n¹).

Gibaja, J.F., 2008. Anàlisi funcional de les restes lítiques tallades. In: Alcalde, G., Saña, M. (Eds.), Procés d'ocupació de la Bauma del Serrat del Pont (La Garrotxa) entre 7400 i 5480 Cal aC. Publicacions Eventuals d'Arqueologia de la Garrotxa. Museu Comarcal de la Garrotxa, Olot, pp. 53-59.

Gonçalves, V.S., 2003. Comer em Reguengos no Neolítico: o sítio XZ-12. In: Gonçalves, V.S. (Ed.), Muita gente, poucas antas? Espaços, Origens e Contextos do Megalitismo. Actas do $2^{\circ}$ Colóquio internacional sobre Megalitismo. Reguengos de Monsaraz, 2000. Instituto Português de Arqueologia, Lisboa.

Gonçalves, V.S., Marchand, G., Sousa, A.C., 2008. Mudança e permanência do Mesolítico final ao Neolítico (Reguengos de Monsaraz, Évora, Portugal). In: Hernandez Perez, M.S., Soler Díaz, J.A., Lopez Padilla, J. (Eds.), Actas del IV Congreso del Neolítico Peninsular. vol. 2. Museo Arqueológico de Alicante, II, Alicante, pp. 167-177.

Gonçalves, V.S., Sousa, A.C., Marchand, G., 2013. Na margem do Grande Rio. 1. Os últimos grupos de caçadores-recolectores e as primeiras sociedades camponesas no baixo Guadiana. DRCALEN/EDIA, Évora, pp. 616.

Igreja, M., 2013. Estudo traceológico: vestígios de uso resultantes da função e do modo de funcionamento de artefactos líticos da Barca do Xerez de Baixo. In: Araújo, A.C., Almeida, F. (Eds.), Barca do Xerez de Baixo. Um testemunho invulgar das últimas comunidades de caçadores-recolectores. Direcção Regional de Cultura do Alentejo, Évora, pp. 307-323.

Marchand, Gregor, Michel, Sylvène, Quesnel, Laurent, Sellami, Farid, Bertin, Francis, Blanchet, François, Crowch, Aurélie, Dumarçay, Gaelle, Pierrick, Fouéré, Quesnel, Laurent, Tsobgou-Ahoupe, Rodrigue, 2007. Un habitat de la fin du Mésolithique dans le Centre-Ouest de la France: L'Essart à Poitiers (Vienne). L Anthropologie 111 (1), 10-38. http://dx.doi.org/10.1016/j.anthro.2006.12.015.

Marchand, Gregor, Michel, Sylvène, Quesnel, Laurent, Sellami, Farid, 2008. Les structures de combustion de L'Essart (Poitiers, Vienne, France): ses epandages de pierres au fonctionnement d'un habitat mesolithique. In: Aubry, Thierry, Almeida, Francisco, Araújo, Ana Cristina, Tiffagom, Marc (Eds.), Session C64. Space and Time: Which Diachronies, Which Synchronies, Which Scales? Session C65. Typology vs. Technology. Archaeopress. BAR International Series 1831, Oxford, pp. 101-108.

Mazo, C., 2006. Análisis de huellas de uso de la serie lítica retocada del nivel IV de Mendandia. In: Fundación, B.P., Barandiarán, J.M. (Eds.), El campamento prehistórico de Mendandia: ocupaciones mesolíticas y neolíticas entre el 8800 y el 6400. Diputación Foral de Álava, Vitoria-Gasteiz, pp. 285-320.

Mazzucco, N., Gibaja, B.A.O.J.F., Perales, B.A.R.R.Ó.N.U., San, M.I.L.L.Á.N.L.O.M.A.S.M., García, P.U.C.H.O.L.O., Rojo, G.U.E.R.R.A.M., Royo, G.U.I.L.L.É.N.J.I., GarcíaMartínez, D.E.L.A.G.R.Á.N.I., Juan, C.A.B.A.N.I.L.L.E.S.J., García, G.A.Z.O.L.A.Z.J., Gassin, B., 2016. Insights into the Late Mesolithic toolkit: use-wear analysis of the notched blades. Case-studies from the Iberian Peninsula. Preistoria Alpina 48, 151-157.

Mcparland, Laura C., Collinson, Margaret E., Scott, Andrew C., Campbell, Gil, Veal, Robyn, 2010. Is vitrification in charcoal a result of high temperature burning of wood? J. Archaeol. Sci. 37, 2679-2687. http://dx.doi.org/10.1016/j.jas.2010.06. 006.

Orliac, M., 2003. Diversité morphologique et fonctionelle des fours polynésiens. In: FréreSautot, M.-C. (Ed.), Le feu domestique et ses strutures au Néolithique et aux Âges des métaux. Actes du colloque de Bourg-en-Bresse et Beaune. Éditions Mónique, Mergoil, Montagnac, pp. 67-70.

Queiroz, Paula, 2013. Identificação botânica de cinco amostras de material vegetal carbonizado - Cova da Baleia, Cabeço do Pé da Erra e Barranco do Farinheiro. In: Terra Scenica-Território Antigo Relatórios, (Unpublished report, Lisboa. 6 pp.).

Queiroz, Paula, van Leeuwaarden, Win, 2004. Estudos de Arqueobotânica no Concheiro de São Julião (Mafra). In: Sousa, A.C. (Ed.), São Julião, Núcleo C do Concheiro PréHistórico. Cadernos de Arqueologia de Mafra, 2, Mafra: Câmara Municipal de Mafra, pp. 117-134.

Ramseyer, D., 2003. Fours, foyers et autres strutures de combustion, Ethnoarcheologie chez les Kouyas de Côte-d'Ivoire. In: Frére-Sautot, M.-C. (Ed.), Le feu domestique et ses strutures au Néolithique et aux Âges des métaux. Actes du colloque de Bourg-enBresse et Beaune. Éditions Mónique Mergoil, Montagnac, pp. 225-229.

Reimer, P.J., et al., 2013. Intcal13 and Marine13 Radiocarbon Age Calibration Curves 0-50,000 Years Cal BP. Radiocarbon 55 (4), 1869-1887.

Rodríguez, A., 1993. L'analyse fonctionnelle de l'industrie lithique du gisement epipaleolithique/mesolithique d'el Roc de Migdia (Catalogne-Espagne). Resultats preliminaires. Préhistoire Européenne 4, 63-84.

Santos, F., Carvalho, P.S., 2008. O sítio neolítico da Defesa de Cima 2 (Torre de Coelheiros, Évora). Primeiros resultados. pp. 56-68 (Vipasca. Aljustrel, $\mathrm{n}^{\circ} 2$ 2, $2^{\mathrm{a}}$ série. [III Encontro de Arqueologia do Sudoeste Peninsular]).

Schweingruber, Fritz H., 1990. Anatomy of European Woods. Paul Haupt and Stuttgart Publishers.

Silva, C.T., Soares, J., 2016. The Pleistocene-Holonece transition on the Portuguese southwest coast- a zer stage of social complexity? In: Soares, J. (Ed.), Social Complexity in a Long Term Perspective. Setúbal Arqueológica, vol. 16. pp. 21-40.

Sousa, A.C., Gonçalves, V.S., 2015. Fire walk with me. O sítio de Cova da Baleia e as primeiras arquitecturas domésticas de terra e fogo no Centro e Sul de Portugal. In: 
Gonçalves, V.S., Dinz, M., Sousa, A.C. (Eds.), Actas do $5^{\circ}$ Congresso do Neolítico Peninsular. UNIARQ, Lisboa, pp. 123-142. http://hdl.handle.net/10451/28060.

Sousa, A.C., Soares, A.M., 2016. Continuity or discontinuity? Aquatic exploitation in the portuguese Estremadura during the Atlantic period: São Julião and Magoito shell middens as case studies. In: Sea people 2014 - Colloque Rennes. Societé Pré-historique Française, pp. 191-212.

Stahl, P.W., Oyuela-Caycedo, A., 2007. Early prehistoric sedentism and seasonal animal exploitation in the Caribbean lowlands of Colombia. J. Anthropol. Archaeol. 26, 329-349. http://dx.doi.org/10.1016/j.jaa.2007.02.004.

Stuiver, M., Reimer, P.J., 1993. Extended 14C data base and revised CALIB $3.014 \mathrm{C}$ age calibration program. Radiocarbon 35, 215-230.
Théry-Parisot, Isabelle, Henry, Auréade, 2012. Seasoned or green? Radial cracks analysis as a method for identifying the use of green wood as fuel in archaeological charcoal. J. Archaeol. Sci. 39, 381-388. http://dx.doi.org/10.1016/j.jas.2011.09.024.

Vernet, Jean-Louis, Ogereau, Paule, Figueiral, Isabel, Machado-Yanes, Carmen, Uzquiano, Paloma, 2001. Guide d'identification des charbons de bois préhistoriques et récents. Sud-Ouest de l'Europe: France, Péninsule ibérique et îles Canaries. CNRS Editions, Paris.

Zambujo, Gertrudes, Lourenço, Sandra, 2002. Duas novas datações absolutas para a Ponta da Vigia (Torres Vedras). Rev. Port. Arqueol. 6 (1), 69-78 (Lisboa).

Zilhão, João, 1997. O Paleolítico Superior da Estremadura Portuguesa. Colibri, Lisboa (2 vols). 